\title{
Environmental impacts of small-scale hybrid energy systems: Coupling solar photovoltaics and lithium-ion batteries
}

Dol:

10.1016/j.scitotenv.2018.06.290

\section{Document Version}

Accepted author manuscript

Link to publication record in Manchester Research Explorer

Citation for published version (APA):

Uctug, F. G., \& Azapagic, A. (2018). Environmental impacts of small-scale hybrid energy systems: Coupling solar photovoltaics and lithium-ion batteries. Science of the Total Environment, 643.

https://doi.org/10.1016/j.scitotenv.2018.06.290

Published in:

Science of the Total Environment

\section{Citing this paper}

Please note that where the full-text provided on Manchester Research Explorer is the Author Accepted Manuscript or Proof version this may differ from the final Published version. If citing, it is advised that you check and use the publisher's definitive version.

\section{General rights}

Copyright and moral rights for the publications made accessible in the Research Explorer are retained by the authors and/or other copyright owners and it is a condition of accessing publications that users recognise and abide by the legal requirements associated with these rights.

\section{Takedown policy}

If you believe that this document breaches copyright please refer to the University of Manchester's Takedown Procedures [http://man.ac.uk/04Y6Bo] or contact uml.scholarlycommunications@manchester.ac.uk providing relevant details, so we can investigate your claim.

\section{OPEN ACCESS}




\title{
Environmental impacts of small-scale hybrid energy systems: Coupling solar photovoltaics and lithium-ion batteries
}

\author{
Fehmi Gorkem Üçtuğ ${ }^{1 *}$ and Adisa Azapagic ${ }^{2}$ \\ ${ }^{1}$ Izmir University of Economics, Faculty of Engineering, Sakarya Caddesi No: 15635330 \\ Balçova - Izmir, Turkey \\ ${ }^{2}$ Sustainable Industrial Systems, School of Chemical Engineering and Analytical Science, \\ The University of Manchester, Manchester, M13 9PL, UK, \\ *Corresponding author: gorkem.uctug@ieu.edu.tr; gorkem.uctug@yahoo.com
}

\begin{abstract}
One of the benefits of hybrid solar PV-battery systems is that they can reduce grid dependency and help balance electricity supply and demand. However, their environmental impacts and benefits remain underexplored. This study considers for the first time life cycle environmental impacts of domestic-scale PV-battery systems in Turkey, integrating multicrystalline PV and lithium-ion battery. The impacts were estimated for both individual installations and at the national level, considering different regions across the country and taking into account their insolation and other climatic differences. Electricity generation and storage were modelled on an hourly basis taking into account consumer behaviour. The results show that the system can meet between $12.5 \%$ and $18.4 \%$ of the household's annual electricity needs. On a life cycle basis, it generates 4.7-8 times more energy than it consumes. Solar PV is the major contributor to most impacts (75\%-81\%). An exception is human toxicity which is mainly due to the battery $(66 \%)$. The hybrid system has $1.6-82.6$ times lower impacts than grid electricity. Assuming a very modest uptake at the national level (2\%-8\%), the use of hybrid systems would save 558,000 t $\mathrm{CO}_{2}$-eq./yr compared to grid electricity. Thus, these results demonstrate clearly the environmental benefits of these hybrid systems. Together with the financial and energy security benefits for both the country and the consumer, this provides a strong impetus for their wider deployment. However, this will be difficult to achieve, as there are no incentives for battery storage. Therefore, it is recommended that relevant legislation be introduced to stimulate future uptake of hybrid PV-battery systems.
\end{abstract}

Keywords: environmental impacts; hybrid energy systems; life cycle assessment; lithium-ion batteries; solar photovoltaics (PV); Turkey.

\section{Introduction}

Renewable energy sources are becoming more common, both for large and small scale applications. Some of the driving factors for this trend include concerns about security of energy supply, climate change and a desire to utilise local resources and improve national economies (Baranes, et al., 2017). Given that the worldwide energy demand is projected to grow by almost $40 \%$ by 2040 , it is expected that renewable energy will continue to bear significance in the global energy portfolio (Unites States Energy Information Administration, 2016). Buildings account for approximately $31 \%$ of global energy consumption (IEA, 2016) which is still largely derived from fossil fuels. Hence, switching to renewable energies in the building sector could bring significant benefits, including lower greenhouse gas emissions and increased security of energy supply (Leonard \& Michaelides, 2018). 
Among renewable energy technologies, solar photovoltaics (PV) have seen a considerable growth and uptake in many countries, supplying more than 1\% of the demand in 2015 (Solar Power Europe, 2017). This has been driven largely by the feed-in-tariff incentives, providing payments to 'prosumers' for generating electricity and feeding it back to the grid. The main reason for promoting solar PV is that they can help mitigate climate change due to their low carbon emissions on a life cycle basis, as demonstrated by numerous life cycle assessment (LCA) studies (Gerbinet, et al., 2014; Liu, et al., 2015; Gong, et al., 2015; Hou, et al., 2016; Wong, et al., 2016). They also have various other advantages. For example, PV panels convert sunlight directly to electricity silently and require little maintenance; they are also reliable, modular and rapidly deployable (Corkish \& Prasad, 2006).

However, PV systems also have one main disadvantage: the intermittency. They cannot generate electricity in a continuous, reliable manner as solar radiation may not be present at all or it may not be at the desired level at all times during the day, depending on the location. Therefore, the following situations are often observed: PV systems fail to meet the instantaneous demand for most of the day, or they generate much more electricity than needed at certain times (Akbari, et al., 2018). Hence, coupling a PV system with a battery is essential to decreasing the grid dependency and balancing supply and demand (Jossen, et al., 2004). Coupling a PV system with a battery enables the user to store the excess amount of electricity generated during a low demand and then use this electricity when the generation fails to match the demand. Depending on the load profile and the location, it can be possible to achieve a net zero energy status, with buildings generating at least the same amount of electricity as they consume over a year (Ferrari \& Beccali, 2017). However, some studies have shown that this may not always be the case and may depend on many factors (Balcombe, et al., 2015). Nevertheless, the economic and environmental benefits of using a hybrid system that integrates solar PV with battery energy storage could be significant, particularly in countries with high contribution of fossil fuels in the electricity mix and a fast-growing population.

Turkey is one such country, where population is growing at an average rate of $1.4 \%$ per year (Turkish Institute of Statistics, 2016) and the annual electricity demand is expected to reach 802 TWh by 2035 (Republic of Turkey - Ministry of Energy, 2013). More than 90\% of Turkey's primary energy demand is supplied by fossil fuels (International Energy Agency, 2013). Only $28.5 \%$ of the primary energy demand is met by domestic resources with the rest being imported (Turkyilmaz, 2015). Virtually all (99\%) of the annual natural gas and $89 \%$ of oil consumption in Turkey is met via imports, costing the country US\$60 billion (International Energy Agency, 2016). The only considerable local source of conventional energy is lignite; however, its quality is very low as it contains high sulphur and ash content (Atilgan \& Azapagic, 2016). Hence, minimising the use of fossil fuels is of utmost importance for Turkey, from both economic and environmental points of view.

Turkey is ideally suited for utilising solar power as it lies in a sunny belt with an average of 2640 hours of sunshine per year and solar radiation of $3.6 \mathrm{kWh} / \mathrm{m}^{2}$ per day (Çakay, 2003). The total solar energy potential of the country is estimated at $380 \mathrm{TWh}$ per annum (Kaygusuz \& Sar1, 2003; Turkyilmaz, 2015). However, despite being one of the world leaders in the number of installations of solar water-heating systems (Altuntop \& Erdemir, 2013; Üçtuğ \& Azapagic, 2018), the utilisation of PV systems in Turkey has been progressing relatively slowly. As of 2016, electricity generated by solar PV accounted for only $0.2 \%$ of the annual electricity generation (International Energy Agency, 2016). Almost all of it comes from small-scale $(<1 \mathrm{MW})$ 'unlicensed' systems which can sell the excess electricity back to the grid at variable feed-in-tariff rates. Large-scale 'licensed' generation $(>1 \mathrm{MW})$ has started 
only very recently and the country's target is to have $5 \mathrm{GW}$ of total installed solar power capacity by 2030 (Enerji Gunlugu, 2014). As one of the participating countries at the Paris COP21 Conference in 2015, an increase in the uptake of solar PV systems could help Turkey to meet its climate change target of reducing greenhouse gas (GHG) emissions by $21 \%$ by 2030 (UNFCCC, 2017).

However, the potential GHG and other environmental benefits of utilising solar PV systems in Turkey are unknown, particularly when coupled with battery storage. Therefore, this paper estimates for the first time the environmental impacts of hybrid systems combining solar PV and battery storage installed in domestic buildings in different regions in Turkey. The impacts are considered both at the level of individual installations and across the whole country, taking into account regional insolation levels and the hourly household energy demand. The impacts are estimated on a life cycle basis, using LCA as a tool. While there are several previous LCA studies of solar PV, batteries and their combination elsewhere in the world, as far as we are aware, this is the first study to consider a hybrid system integrating solar PV and battery storage in Turkey.

The next section provides an overview of previous relevant LCA studies, before detailing in section 3 the methods used in the study. The results are presented and discussed in section 4 and conclusions are drawn in section 5.

\section{Literature review}

\subsection{LCA of solar PV systems}

The energy output of PV systems depends strongly on the location and so do their life cycle impacts per unit of electricity generated ( $\mathrm{Li}$, et al., 2016; Li, et al., 2017). To explore the effect of the location on the impacts, Lamnatou and colleagues conducted an LCA of concentrating PV systems for building-integrated applications (Lamnatou, et al., 2015). They calculated the energy and GHG payback times for installations in the following cities in the UK, Ireland, Spain and France: Exeter, Dublin, Barcelona, Madrid and Paris. The payback periods were found to vary between 2.5 and 3.5 years and, as expected, the locations in southern latitudes had lower payback periods. Concentrating PV systems for building applications in Spain were also considered in another study (Menoufi, et al., 2013) which found a significant reduction in the impacts compared to conventional mono-crystalline silicon PV installations.

The latter were compared with multi-crystalline systems for installations in Spain and the UK (Stamford \& Azapagic, 2018), showing that the both types of systems had 60\% lower impacts in Spain than the UK. Furthermore, multi-crystalline systems had on average around $10 \%$ higher impacts regardless of the installation region.

Another study (Bekkelund, 2013) considered the impacts of mono-crystalline solar PV for the Norwegian conditions, in comparison with two thin-film technologies: cadmium telluride (CdTe) and copper indium gallium selenide (CIGS). These were found to have significantly lower impacts than the mono-crystalline option. For instance, global warming potential of the latter was estimated at $208 \mathrm{~kg} \mathrm{CO}$-eq. $/ \mathrm{m}^{2}$, while that of CdTe and CIGS was 75 and $86 \mathrm{~kg}$ $\mathrm{CO}_{2}$-eq. $/ \mathrm{m}^{2}$, respectively. Silicon extraction and purification were the main cause of the higher impacts for the mono-crystalline PV.

$\mathrm{Fu}$ and colleagues focused on multi-crystalline PV systems in China (Fu, et al., 2015). The primary energy demand was estimated at $12.61 \mathrm{MJ} / \mathrm{W}$ and the energy payback period ranged 
between 2.2 and 6.1 years, depending on the location. Similar to the mono-crystalline study by Bekkelund (2013), silica extraction and purification were also the main contributors to the environmental impacts of the multi-crystalline system.

Some studies considered the manufacturing of solar PV in different countries to demonstrate the effect on the impacts. For example, Nian compared mono- and multi-crystalline systems produced in a number of countries (Nian, 2016): Australia, China, France, Germany, Japan, Norway, Singapore, South Korea, Taiwan and the United States. The impacts of manufacturing per kWh of electricity generated were found to be the highest in Australia, twice as high as in France. Mono-crystalline systems had approximately 80\% higher global warming potential than the multi-crystalline. Furthermore, Stamford and Azapagic (2018) found that the shift of manufacturing from Europe to China in the period 2005-2015 has increased environmental impacts by an average of 9\%-13\%, negating the technological progress over the period.

\subsection{LCA of batteries}

A few LCA studies of different types of battery are available, for both stationary and mobile applications. Given the focus in this work, only stationary applications are discussed below.

A review of environmental impacts of lithium-ion batteries for stationary applications found that, on average, $1 \mathrm{kWh}$ of storage capacity is associated with a cumulative energy demand of $328 \mathrm{kWh}$ and emissions of $110 \mathrm{~kg} \mathrm{CO}_{2}$-eq. (Peters, et al., 2017). It was also noted that most studies considered only global warming potential, omitting other environmental impacts.

In a comparative study of the global warming potential of lithium-ion and nickel metal hydride batteries (NiMH), Liang and co-workers showed that the former had a factor of ten lower impact than the latter (12.7 vs $124 \mathrm{~kg} \mathrm{CO}_{2}$-eq. (Liang, et al., 2017)). On the other hand, another study (McManus, 2012) found that both types had much higher impacts than lead acid, nickel cadmium and sodium sulphur batteries, especially global warming potential and depletion of metals. However, the cumulative energy demand of lithium-ion batteries was relatively low (150 MJ per MJ of battery capacity) compared to nickel cadmium $(\approx 200$ $\mathrm{MJ} / \mathrm{MJ})$ and nickel metal hydride $(\approx 300 \mathrm{MJ} / \mathrm{MJ})$ batteries.

\subsection{LCA of hybrid PV-battery systems}

Most LCA studies of hybrid systems focused on multi-crystalline PV and lead-acid batteries and compared the results to the grid electricity. For example, a study based in Lebanon (Kabakian, et al., 2015) found that such a hybrid system had lower environmental impacts than the electricity from the grid. The authors also reported that the impacts of the battery were negligible compared to those of the PV. For instance, the global warming potential of the hybrid system was $40.2 \mathrm{~g}$ of $\mathrm{CO}_{2}$-eq./kWh and without the battery, $38.9 \mathrm{~g}$. Similarly, there was a very small difference in the cumulative energy demand with and without the battery (4.41 vs $4.39 \mathrm{MJ} / \mathrm{kWh}$, respectively). Overall, the addition of the battery did not increase the impacts more than $3 \%$.

A similar trend was reported by Belmonte et al. (2016) who compared the global warming potential of two hybrid systems installed in Italy, both with multi-crystalline PV but one with lithium-ion battery and another with proton-exchange-membrane fuel cell. The system with the battery had a lower impact than the one with the fuel cell. Like Kabakian et al. (2015), this study also found that the majority of the impact (80\%) from the PV-battery system was caused by solar PV. 
In a study based in the UK, Balcombe et al. (2015) studied the impacts of a microgeneration system combining multi-crystalline solar PV, Stirling engine and lead-acid battery. Most environmental impacts were found to be lower by $35 \%$ to $100 \%$ than for the equivalent amount of electricity from the grid and heat from a gas boiler. However, the depletion of elements increased by a factor of 42 due to the use of antimony in batteries.

Hybrid systems with the lead-acid battery were also considered by Dufo-Lopez et al. (2011). They compared the impacts of coupling this type of battery with mono-crystalline PV, wind turbine or diesel generator. Based in Spain, the study found that the PV-based system had the lowest impacts (Dufo-López, et al., 2011).

As mentioned earlier, no LCA studies of hybrid PV-battery systems were found for Turkey. Therefore, this is the first study for this region. The specific technologies considered are multi-crystalline PV and lithium-ion battery. This type of solar PV was selected as it occupies the majority (70\%) of the global market share (Fraunhofer Institute for Solar Energy Systems, 2016). A lithium-ion battery was chosen because of its superior technical performance compared to the other types, with higher power and energy densities as well as durability (Rudolf \& Papastergiou, 2013). As discussed above, only one LCA study of such a hybrid system was found in the literature, based in Italy (Belmonte, et al., 2016); however, like most other studies of hybrid systems, it only considered global warming potential.

This work goes beyond the current state-of-the-art to consider a range of environmental impacts. A further novelty includes estimation of the impacts for a range of different geographical regions in Turkey, covering the full spectrum of solar irradiation across the whole country. Moreover, electricity generation and storage were modelled on an hourly basis taking into account consumer behaviour. The next section provides more details on this, together with the methods, assumptions and data used in the study.

\section{Methods}

The study follows the ISO 14040/44 guidelines (ISO, 2006a; ISO, 2006b) for LCA methodology, starting with the goal and scope definition in the next section and followed by inventory data in section 3.2. The CML 2001 (Guinée, et al., 2002) impact assessment method was used and the following impacts were considered: global warming potential (GWP), acidification potential (AP), eutrophication potential (EP), ozone layer depletion potential (OLDP), photochemical oxidant creation potential (POCP), and human toxicity potential (HTP). In addition, the energy payback period was also estimated, as detailed further below. The system was modelled and the impacts calculated using the CCaLC software (CCaLC, 2016).

\subsection{Goal and scope definition}

The goals of the study were as follows:

i) to estimate the environmental impacts of the hybrid system integrating solar PV and a lithium-ion battery and identify the hotspots;

ii) to compare the impacts with the grid electricity and identify any environmental benefits from using the hybrid system; and

iii) to determine the environmental implications of deploying such a hybrid system across Turkey, taking into account household hourly energy demand and solar irradiation in different climatic regions. 
The scope of the study was from cradle to grave (Figure 1), encompassing extraction and processing of raw materials, the manufacture of the solar PV and the battery, their installation and use and end-of-life waste management. The system consists of $1 \mathrm{kWp}$ solar PV with 1 $\mathrm{kW}$ inverter and $2.1 \mathrm{kWh}$ lithium-ion battery. The reason for choosing this size of the system is largely the affordability as larger systems would be too expensive for most income groups in Turkey. Furthermore, this capacity of lithium-ion batteries, which have to be imported, is readily available on the international market (Murata, 2018). The total lifetime of the system was assumed at 25 years, corresponding to the lifespan of the solar PV unit (Kabakian, et al., 2015). However, the lifetime of the battery was assumed to be 10 years (Hesse, et al., 2017), requiring its two replacements over the lifespan of the whole system. It was also assumed that no maintenance of the system was required.

For the first two goals of the study, the functional unit was defined as $1 \mathrm{kWh}$ of electricity supplied by the system. For the analysis at the national level (third goal), the functional unit was the total annual energy demand by households in detached houses in Turkey. The reason for choosing detached houses is the larger roof area available for PV panels. Furthermore, such households are in a higher-income group and more likely to be able to afford these systems. The detached houses provide accommodation for approximately $40 \%$ of the Turkish population (Üçtuğ \& Azapagic, 2018), so the impacts at the national level refer to this proportion of the population.

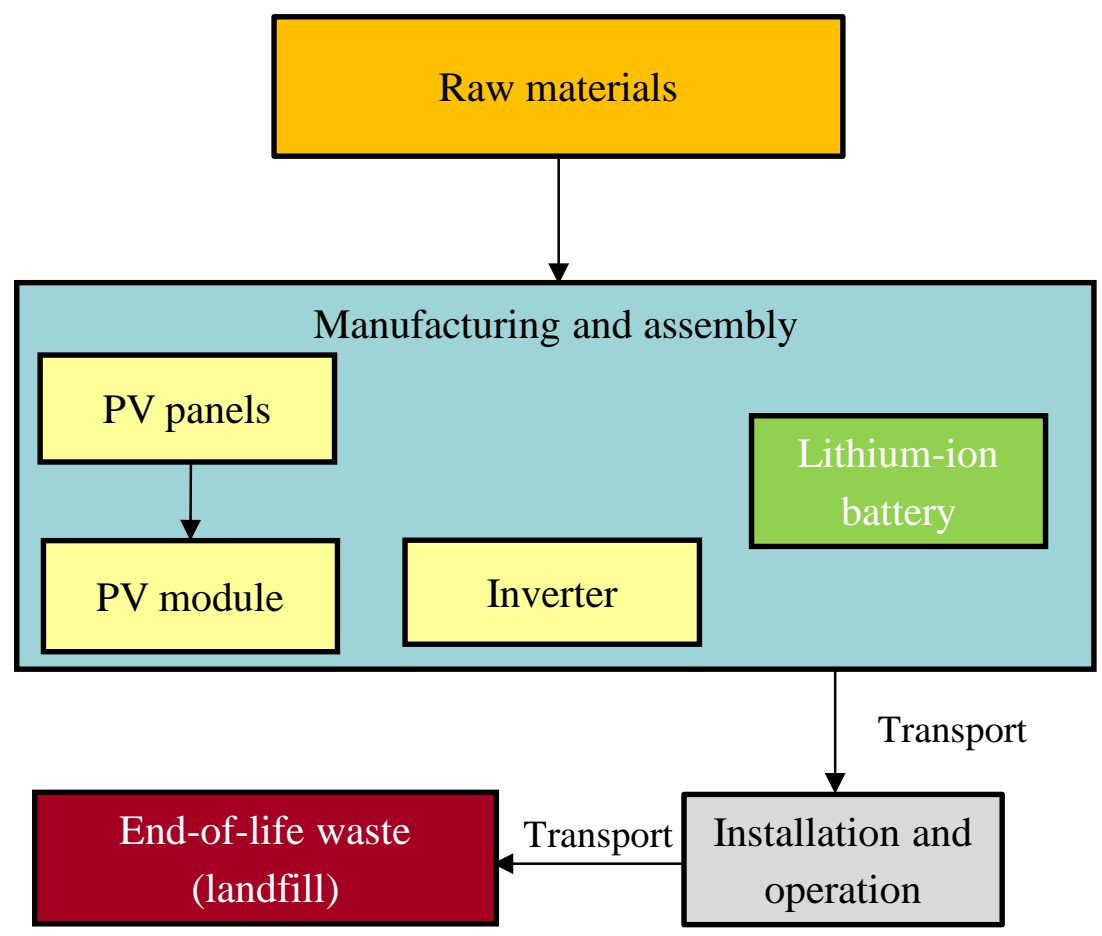

Figure 1. System boundaries and the life cycle stages considered in the study

\subsection{Inventory data}

The technical data for the system can be found in Table 1. Solar PV panels with the installed capacity of $1 \mathrm{kWp}$ occupy an approximate area of $6 \mathrm{~m}^{2}$ (Üçtuğ \& Yükseltan, 2012). Increasing the system capacity would increase the energy generation but, as mentioned earlier, it would not be technically or economically feasible for many households due to the increased area requirement and higher system costs. 
Table 1. Specification of the PV-battery system

\begin{tabular}{llll}
\hline PV panel & & Li-ion battery & \\
\hline Parameter & Value & Parameter & Value \\
\hline AC system size & $1 \mathrm{kWp}$ & Nominal voltage & $51.2 \mathrm{~V}$ \\
Module type & $\begin{array}{l}\text { Standard multi- } \\
\text { crystalline }\end{array}$ & $\begin{array}{l}\text { Maximum } \\
\text { discharge current }\end{array}$ & $50 \mathrm{~A}$ \\
& Wixed (rooftop) & Weight & $27 \mathrm{~kg}$ \\
Array type & Fimensions & $\mathrm{W} 215 \times \mathrm{H} 160 \times \mathrm{D} 522(\mathrm{~mm})$ \\
System losses & $15 \%$ & & \\
Tilt & $33.7^{\circ}$ & & \\
Azimuth & $180^{\circ}$ & & \\
\hline
\end{tabular}

The inventory data for the different parts of the systems are detailed in Table 2. Currently, there is no production of PV panels in Turkey, only the module assembly. Therefore it was assumed that the panels are manufactured in China and then transported to Turkey for assembly into a PV system. Similarly, there is no production of lithium-ion batteries in Turkey either and it was assumed that they are imported from Germany. The transportation details can be found in Table 3 and Table 4. Only the transport of the finished products was considered; transport of the raw materials was excluded due to a lack of data. The data on waste management are summarised in Table 5; all materials were assumed to be landfilled due to a lack of recycling facilities for these systems in Turkey. Country-specific inventory data were used as much as possible. The data for the PV manufacturing are for the production in China (Fu, et al., 2015) whereas the PV module assembly data were obtained from the assembly industry in Turkey and from the literature. For the manufacturing of the lithium-ion battery and the inverter, data from Ecoinvent v2.2 were used (Ecoinvent, 2017).

To enable consideration of different power outputs of the PV system depending on the geographical location, the systems were assumed to be installed in seven cities, situated in seven different regions across Turkey. The selected cities are shown in Figure 2. These cities were selected because they all lie more or less in the central part of their respective geographical regions. Therefore, it was assumed that the solar irradiation for each city is representative of the entire region where they are situated.

The data for hourly electricity generation by the PV systems in each city were estimated using the NREL tool (pvwatts.nrel.gov, 2017). In cases where no data were available for the selected location, data for the nearest location were used instead.

\subsection{Estimation of electricity supply and consumption}

To carry out the LCA, it was necessary to determine the energy flows into, within and out of the hybrid system, including generation by solar PV, storage and supply by the battery and imports from the grid. As detailed further below, these were estimated at hourly intervals. The main challenge, however, was to determine the hourly consumption patterns based on households' habits and behaviours. As these data are not readily available, they were collected as part of this study, making certain assumptions, as described next. 
Table 2. Inventory data for the PV-battery system (Fu, et al., 2015; International Energy Agency, 2011; Atilgan \& Azapagic, 2016; Ecoinvent, 2017)

\begin{tabular}{|c|c|c|c|c|}
\hline Material & Ecoinvent data set & Process & Unit & Amount \\
\hline \multicolumn{5}{|c|}{ Manufacture of PV panels (China) } \\
\hline PV cell factory & Photovoltaic cell factory & Production of $150,000 \mathrm{t}$ wafer over 25 years & $\mathrm{kWp}^{-1}$ & $1.33 \times 10^{-10}$ \\
\hline Argon & Argon, liquid, at plant & Ingot casting & $\mathrm{kg}$ & 10.50 \\
\hline Compressed air & Compressed air, average installation, 6 bar gauge, at station & Ingot casting & $\mathrm{kg}$ & 169.80 \\
\hline Electricity & Electricity, medium voltage, at grid, China & Ingot casting & MJ & 157.54 \\
\hline Hydrofluoric acid & Hydrogen fluoride, at plant & Ingot casting & $\mathrm{kg}$ & 0.13 \\
\hline Silicon & Silicon, solar grade, modified Siemens process, at plant & Ingot casting & $\mathrm{kg}$ & 27.60 \\
\hline Sodium hydroxide & Sodium hydroxide, concentrated & Ingot casting & $\mathrm{kg}$ & 0.047 \\
\hline Steam & Steam & Ingot casting & $\mathrm{kg}$ & 7.60 \\
\hline Water & Process water, from ground & Ingot casting & $\mathrm{kg}$ & 492.47 \\
\hline Silicon carbide & Silicon carbide, at plant & Ingot casting \& wafer slicing & $\mathrm{kg}$ & 0.24 \\
\hline Compressed air & Compressed air, average installation, 6 bar gauge, at station & Wafer slicing & $\mathrm{kg}$ & 263.00 \\
\hline Electricity & Electricity, medium voltage, at grid, China & Wafer slicing & MJ & 24.01 \\
\hline Steel wire & steel, hot rolled coil & Wafer slicing & $\mathrm{kg}$ & 17.11 \\
\hline Water & Process water, from ground & Wafer slicing & $\mathrm{kg}$ & 528.63 \\
\hline Adhesive & Adhesive for metals, at plant & $\begin{array}{l}\text { Wafer slicing (for temporary attachment of bricks to } \\
\text { wire-sawing equipment) }\end{array}$ & $\mathrm{kg}$ & 1.22 \\
\hline Glass & Flat glass, uncoated, at plant & $\begin{array}{l}\text { Wafer slicing (for temporary attachment of bricks to } \\
\text { wire-sawing equipment, assumed same as multi-wafers) }\end{array}$ & $\mathrm{kg}$ & 2.47 \\
\hline Acetic acid $(98 \%)$ & Acetic acid, $98 \%$ in $\mathrm{H}_{2} \mathrm{O}$, at plant & Wafer slicing (wafer cleaning) & $\mathrm{kg}$ & 0.60 \\
\hline Deionized water & Water, deionized, at plant & Wafer slicing (wafer cleaning) & $\mathrm{kg}$ & 65.00 \\
\hline $\begin{array}{l}\text { Dipropylene glycol } \\
\text { monomethyl ether }\end{array}$ & Dipropylene glycol monomethyl ether, at plant & Wafer slicing (wafer cleaning) & $\mathrm{kg}$ & 0.30 \\
\hline Sodium hydroxide $(50 \%)$ & Sodium hydroxide, $50 \%$ in $\mathrm{H}_{2} \mathrm{O}$, production mix, at plant & Wafer slicing (wafer cleaning) & $\mathrm{kg}$ & 0.015 \\
\hline Aluminium & Aluminium, primary, at plant & Cell processing & $\mathrm{kg}$ & 0.38 \\
\hline Ammonia & Ammonia & Cell processing & $\mathrm{kg}$ & 0.088 \\
\hline Electricity & Electricity, medium voltage, at grid, China & Cell processing & MJ & 686.69 \\
\hline Ethanol & Ethanol from ethylene, at plant & Cell processing & $\mathrm{kg}$ & 0.23 \\
\hline Hydrochloric acid (30\%) & Hydrochloric acid, $30 \%$ in $\mathrm{H}_{2} \mathrm{O}$, at plant & Cell processing & $\mathrm{kg}$ & 3.17 \\
\hline Hydrofluoric acid & Hydrogen fluoride, at plant & Cell processing & $\mathrm{kg}$ & 0.78 \\
\hline Natural gas & Natural gas, production mix, at service station & Cell processing & $\mathrm{kg}$ & 0.59 \\
\hline Nitric acid & Nitric acid, $50 \%$ in $\mathrm{H}_{2} \mathrm{O}$, at plant & Cell processing & $\mathrm{kg}$ & 2.00 \\
\hline Nitrogen & Nitrogen & Cell processing & $\mathrm{kg}$ & 7.62 \\
\hline Phosphoric acid & Phosphoric acid, industrial grade, $85 \%$ in $\mathrm{H}_{2} \mathrm{O}$, at plant & Cell processing & $\mathrm{kg}$ & 0.0093 \\
\hline Potassium hydroxide & Potassium hydroxide, at regional storage & Cell processing & $\mathrm{kg}$ & 2,76 \\
\hline Silver & Silver, at regional storage & Cell processing & $\mathrm{kg}$ & 0.068 \\
\hline Steam & Steam & Cell processing & $\mathrm{kg}$ & 26.15 \\
\hline Water & Process water, from ground & Cell processing & $\mathrm{kg}$ & 866.04 \\
\hline
\end{tabular}


Assembly of the PV module (Turkey)

\section{$\mathrm{PV}$ module factory \\ Market for photovoltaic panel factory}

Glass

Aluminium

Polyethylene terephthalate

(PET)

Polyvinyl fluoride film

(PVF)

Ethanol

Ethylene vinyl acetate

copolymer (EVA)

Isopropanol

Water

Steam

Electricity

Manufacturing of inverter (Turkey)

Inverter

Solar glass, low iron, at regional storage

Aluminium sheet

Polyethylene terephthalate, $100 \%$ recycled

Polyvinyl fluoride film, at plant

Ethanol from ethylene, at plant

Ethylene vinyl acetate copolymer, at plant

Isopropanol, at plant

Process water, from ground

Steam

Electricity, Turkish mix

Annual production capacity of $300 \mathrm{MW}$ eq. PV modules $\quad \mathrm{kWp}^{-1} \quad 1.33 \times 10^{-7}$ and an operational life time of 25 years

Module assembly

Module assembly

Module assembly

$\begin{array}{lll}\text { Module assembly } & \mathrm{kg} & 3.27\end{array}$

$\begin{array}{lll}\text { Module assembly } & \mathrm{kg} & 0.057\end{array}$

$\begin{array}{lll}\text { Module assembly } & \mathrm{kg} & 7.52\end{array}$

Module assembly $\quad \mathrm{kg} \quad 0.018$

Module assembly $\quad \mathrm{kg} \quad 118.4$

Module assembly $\quad \mathrm{kg} \quad 16.22$

Module assembly $\quad$ MJ $\quad 84.46$

Converting DC to AC

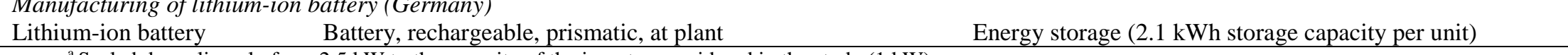

${ }^{a}$ Scaled down linearly from $2.5 \mathrm{~kW}$ to the capacity of the inverter considered in the study $(1 \mathrm{~kW})$

${ }^{b}$ Due to the shorter lifetime of the battery (10 years) compared to the solar PV (25 years), the battery has to be replaced twice (i.e., three batteries are required in total).

Table 3. Transport data (import to Turkey)

\begin{tabular}{lll}
\hline Component & Origin - Destination & Transport mode \\
\hline PV panel & PV manufacturing plant - Shangai Port & Transport, lorry $(>16 \mathrm{t})$, fleet average \\
PV panel & Shangai Port - Kocaeli Port & Container ship \\
PV panel & Kocaeli Port - PV assembly plant (Gebze) $(\mathbf{k m )}$ & Transport, lorry $(>16 \mathrm{t})$, fleet average \\
Lithium-ion battery & Li-ion battery manufacturing plant (Berlin) - Gebze & Transport, lorry $(>16 \mathrm{t})$, fleet average \\
\hline
\end{tabular}

\begin{tabular}{|c|c|c|c|c|c|c|c|c|}
\hline \multirow{2}{*}{$\begin{array}{l}\text { PV-lithium-ion battery } \\
\text { system }\end{array}$} & \multirow{2}{*}{$\begin{array}{l}\text { Origin } \\
\text { Gebze }\end{array}$} & \multicolumn{7}{|c|}{ Destination and distance $(\mathrm{km})$} \\
\hline & & $\begin{array}{l}\text { Marmara } \\
\text { (Istanbul) } \\
65\end{array}$ & $\begin{array}{l}\text { Aegean } \\
\text { (Aydin) } \\
525\end{array}$ & $\begin{array}{l}\text { Mediterranean } \\
\text { (Mersin) } \\
886\end{array}$ & $\begin{array}{l}\text { Central Anatolia } \\
\text { (Kirikkale) } \\
469\end{array}$ & $\begin{array}{l}\text { Eastern Anatolia } \\
\text { (Erzurum) } \\
1,280\end{array}$ & $\begin{array}{l}\text { Black Sea } \\
\text { (Samsun) } \\
682\end{array}$ & $\begin{array}{l}\text { Southeastern } \\
\text { Anatolia (Mardin) } \\
1,420\end{array}$ \\
\hline
\end{tabular}

Table 4. Transport data (within Turkey) ${ }^{\mathrm{a}}$

${ }^{\mathrm{a}}$ Lorry, $>16 \mathrm{t}$

Lithium-ion battery $\quad$ Li-ion battery manufacturing plant (Berlin) - Gebze $\quad$ Transport, lorry $(>16 \mathrm{t})$, fleet average 
Table 5. Waste management data

\begin{tabular}{|c|c|c|}
\hline Component & Ecoinvent dataset & Amount (kg) \\
\hline \multicolumn{3}{|l|}{ Raw materials } \\
\hline Silicon & $\begin{array}{l}\text { Disposal, slag from MG silicon production, } 0 \% \text { water, to inert } \\
\text { material landfill }\end{array}$ & 4.38 \\
\hline Wafer & $\begin{array}{l}\text { Disposal, waste, silicon wafer production, } 0 \% \text { water, to underground } \\
\text { deposit }\end{array}$ & 2.10 \\
\hline PV panel & $\begin{array}{l}\text { Wastewater treatment, PV cell production effluent, to wastewater } \\
\text { treatment, class } 3\end{array}$ & 1227 \\
\hline \multicolumn{3}{|c|}{ End-of-life management } \\
\hline Glass & Disposal, glass, $0 \%$ water, to inert material landfill & $63.26 \mathrm{~kg}$ \\
\hline Glass & Treatment of waste glass, inert material landfill & $63.26 \mathrm{~kg}$ \\
\hline Aluminium & Disposal, aluminium, $0 \%$ water, to sanitary landfill & $11.80 \mathrm{~kg}$ \\
\hline Aluminium & Treatment of waste aluminium, sanitary landfill & $11.80 \mathrm{~kg}$ \\
\hline $\begin{array}{l}\text { Lithium-ion } \\
\text { battery }\end{array}$ & Disposal, Li-ion battery, mixed technology & 3 units \\
\hline
\end{tabular}

300

301

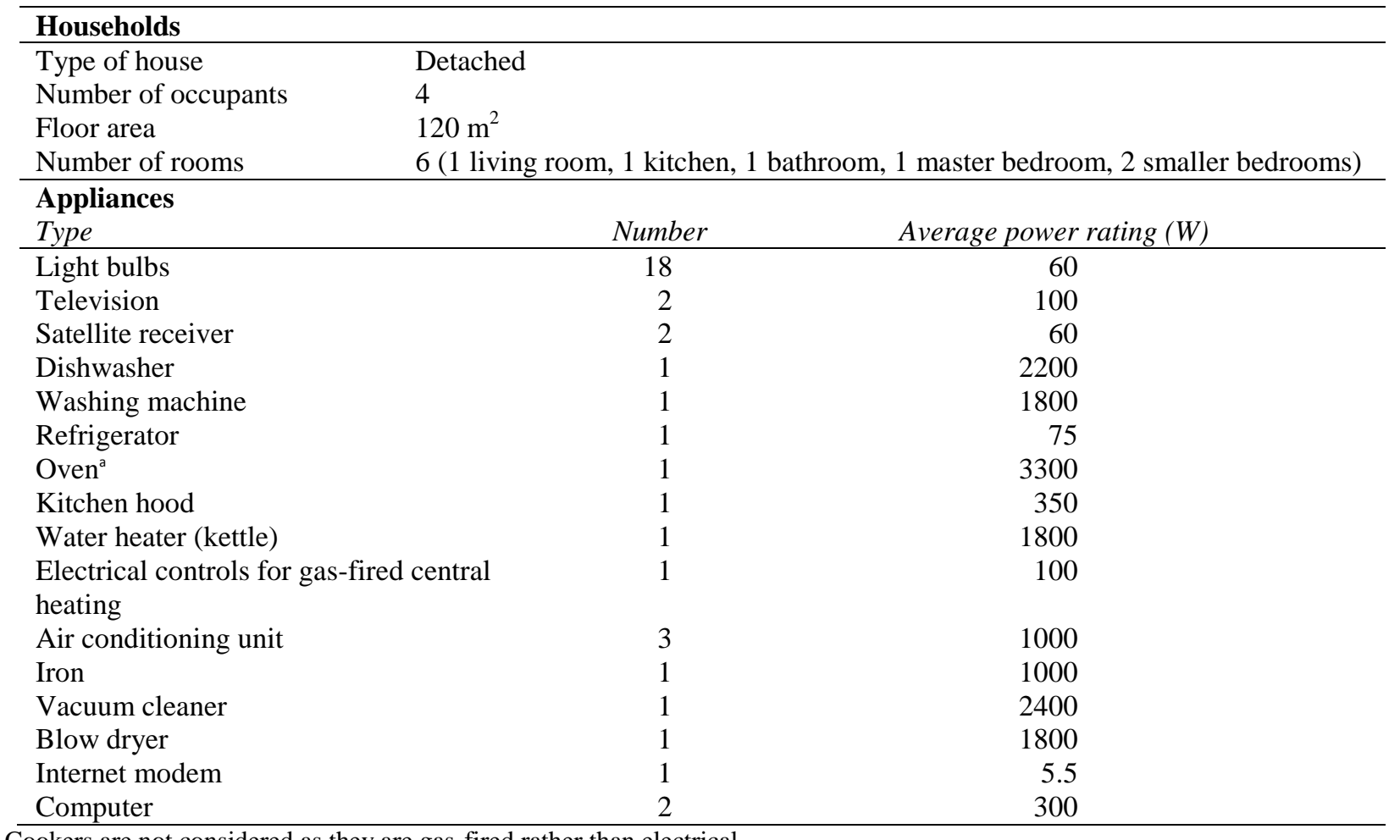

Table 6. Information on the households and appliances 


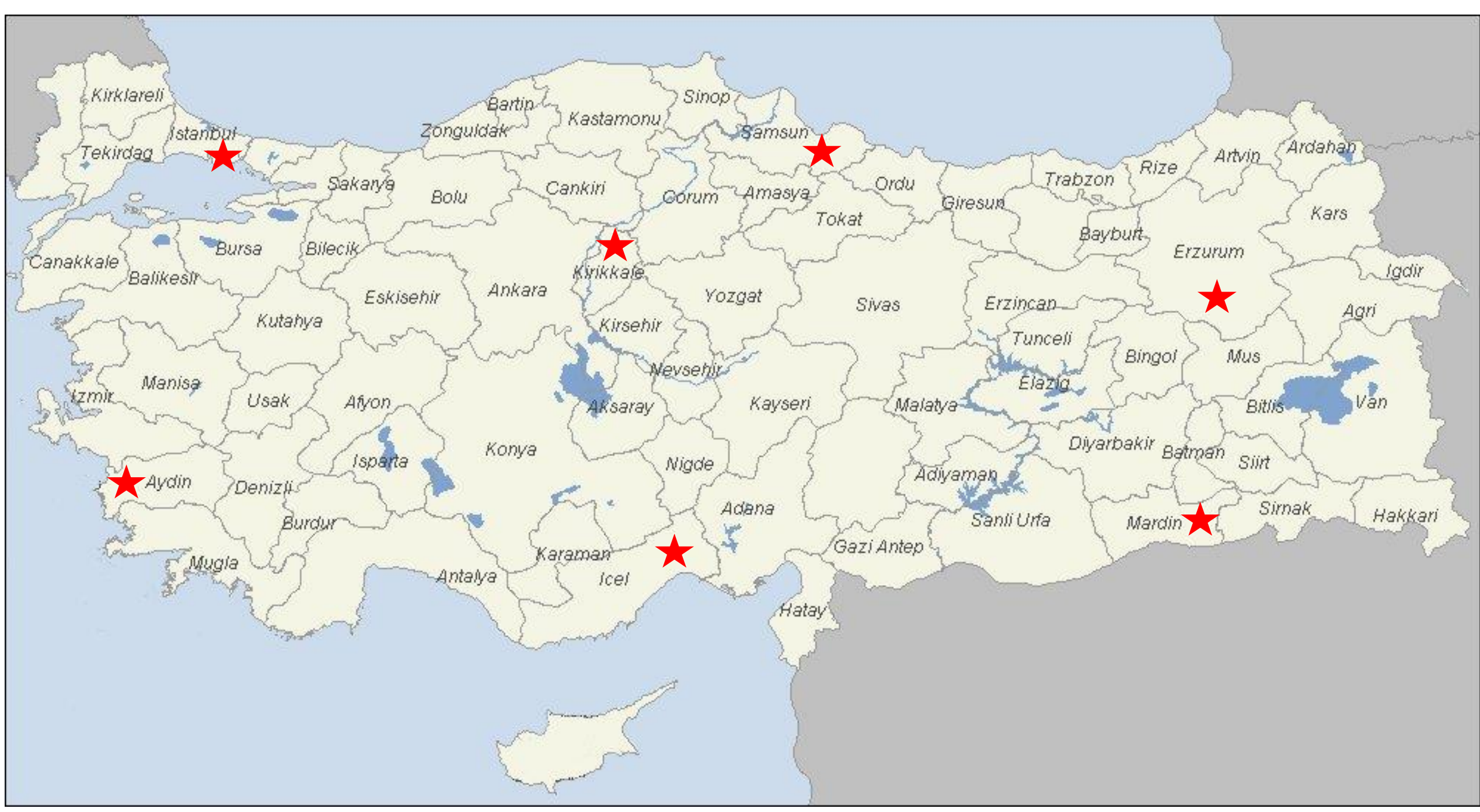

Figure 2. Selected cities in the seven geographical regions of Turkey

[The red stars indicate the location of the cities considered, situated in the following regions: Istanbul - Marmara (northwest); Aydin - Aegean (west); Kirikkale Central Anatolia (centre); Mersin (a.k.a. İçel) - Mediterranean (south); Samsun - Black Sea (north); Erzurum - Eastern Anatolia (east); Mardin - Southeastern Anatolia (southeast)] 
312 First, a typical household size of four people was assumed across all the geographical regions 313 considered (Üçtuğ \& Azapagic, 2018). As only detached houses were considered, they were all 314 assumed to be identical. Secondly, an extensive list of electrical appliances typically used in Turkey 315 was defined, together with their typical power ratings (see Table 6). It was assumed that all the appliances were identical across all the households. However, the use of some of the appliances and the related energy consumption were varied according to the regional climates, as relevant

Thirdly, to obtain energy consumption data, an in-depth survey of a real Istanbul-based household with a PV installation was carried out. A questionnaire was developed for these purposes, which included questions on their eating, working, leisure and sleeping times; how often and at what time of the day they normally used particular appliances; how often they charged their mobile phones, whether they left certain devices on standby, etc. For further details on the questions, see section S1 the Supplementary Information (SI). The questionnaire results were combined with the power rating of the appliances to estimate hourly consumption of electricity over one year, taking into account seasonal requirements for the lighting, heating and air conditioning. It was assumed that the household would behave in the same way in terms of energy consumption throughout the year, with the exception of the aforementioned season-dependent activities. The estimated energy consumption was compared to the actual household's electricity bills for the previous year (before the household had the PV installed) to validate the estimation methodology and the results; this is discussed in the Results and discussion section. Next, we detail the methodology which was used to estimate electricity consumption by the households across the seven regions considered, assuming the same energy consumption pattern across the regions, with the exception of region-specific requirements related to climate. The other parameters that were estimated and are described below include electricity generation by the PV, storage and supply by the battery and the imports from the grid.

The hourly electricity consumption by the households was estimated using the following relationship:
$E C_{h}=\sum_{n}^{N}\left(P_{n} \times \beta_{n, h}\right) / 1000$
$(\mathrm{kWh})$

338 where:

$339 E C_{h}$ total electricity consumption by all appliances in hour $h(\mathrm{kWh})$

$340 \quad P_{n} \quad$ power rating of appliance $n(\mathrm{~kW})$

$341 \quad \beta_{n, h} \quad$ binary value indicating if appliance $n$ is on $(=1)$ or off $(=0)$ in hour $h(-)$.

342

343

The values of $\beta_{n, h}$ were determined based on the type of the appliance and the results of the household survey which indicated when different appliances were used. For example, the TV set or the air conditioning unit had $\beta$ equal to 1 for the time of day when they were being used and zero at other times. For the appliances that are always on, such as refrigerators, $\beta$ was always equal to 1.

347 The electricity generated by the solar PV system is only stored in the battery if the generation is 348 greater than the hourly demand. Thus, the energy stored is equal to the difference between the 349 generation and demand: 
The hourly amounts of electricity generated by the PV were estimated for each of the seven locations using the NREL tool (pvwatts.nrel.gov, 2017), based on the system parameters in Table 1.

The hourly amount of electricity $E I_{h}$ imported from the grid was estimated as:

$E I_{h}=E C_{h}-E G_{h}$

$(\mathrm{kWh})$

The net amount of energy stored by the battery in the first hour of the year considered, $E S N_{l}$, is equal to the amount of energy stored during that hour, i.e.:

$E S N_{1}=E S_{h}$

$(\mathrm{kWh})$

361 For all the remaining 8759 hours of the year, the net stored energy $\operatorname{ESN}_{h}$ is estimated as:

362

$E S N_{h}=E S N_{1}+E S_{h}-E I_{h}$

where $E I_{h}$ is a balance between the consumption and generation as given in eqn. (3). If the estimated $E S N_{h}$ is negative (i.e., the consumption exceeds the generation), it is assigned a value of zero.

The net electricity flow $E N F_{h}$ in and out of the battery is defined as follows:

A positive $E N F_{h}$ value means that electricity is stored in the battery and a negative that it is discharged for use. Therefore, only negative values of $E N F_{h}$ are considered for the estimation of electricity supply $E S U P_{h}$ from the battery:

$E S U P_{h}=0$

$\forall E S U P_{h} \geq 0$

$(\mathrm{kWh})$

An example estimate using eqns. (1)-(7) can be found in Table S1 in the SI.

\subsection{Country-wide implications of using the hybrid system}

The estimates at the level of the individual households, discussed in the previous section, were then used to determine the implications of using the hybrid systems at the level of the whole country. As mentioned earlier, only detached houses were considered and they provide accommodation for around $40 \%$ of the population. Therefore, the number of detached houses with the solar PV-battery system was calculated in each city as follows:

$D H_{c}=O R_{c}\left(P_{c} \times 0.4\right) / 4$

380 where:

$381 D H_{c} \quad$ number of detached houses with the hybrid system in city $c(-)$

$382 O R_{c} \quad$ ownership ratio of the hybrid system in city $c(-)$

$383 \quad P_{c} \quad$ population in city $c(-)$

$384 \quad 0.4 \quad$ population ratio with detached houses (-)

3854 number of people per household (-).

The $\mathrm{OR}_{\mathrm{c}}$ values in different regions were varied from 5\%-20\% as detailed in Table 7. Given that 388 
is equivalent to the overall uptake of $2 \%-8 \%$ at the national level. Two main factors were assumed to determine the ownership ratio: the latitude and the average income of the region's population. The former is important as it determines the energy output and hence the economic viability of the system. For that reason, the assumptions on the potential ownership are quite conservative as it would not be realistic to expect a higher uptake at least in the near future, particularly as there are no financial incentives for batteries.

The $D H_{c}$ values estimated for each city were then summed up to obtain the total number of hybrid systems in Turkey. Overall, 81 cities were considered across the seven geographical regions. The data on the population in the cities and nation-wide consumption of electricity were obtained from the literature (Turkish Institute of Statistics, 2016; Turkish Chamber of Electrical \& Electronics Engineers, 2015). These data were then combined with the electricity generation and supply by the hybrid system, estimated using eqns. (2)-(7), to determine how much of the country's electricity demand could be met by the hybrid systems. These results were then used to estimate the associated environmental impacts of supplying electricity the hybrid systems in comparison with electricity from the grid.

Table 7. Assumed ownership ratios for the hybrid system in different geographical regions

\begin{tabular}{lcl}
\hline Region & Ownership ratio (\%) & Comment \\
\hline Marmara & 10 & High average income (AI), northern latitude \\
Aegean & 15 & High AI, middle and southern latitude \\
Mediterranean & 20 & High AI, southern latitude \\
Central Anatolia & 10 & Medium AI, medium latitude \\
Black Sea & 5 & Medium AI, northern latitude \\
Southeastern Anatolia & 5 & Very low AI, southern latitude \\
Eastern Anatolia & 5 & Low AI, middle and northern latitude \\
\hline
\end{tabular}

\section{Results and discussion}

\subsection{Estimates of electricity supply and consumption}

The estimates of monthly electricity consumption by the surveyed household based in Istanbul is shown in Table 8 . These values represent the total hourly estimates for each month, obtained using eqn. (1). To validate the assumptions and the estimations, they were compared with the actual electricity bills for the previous year. As can be seen in Table 8, the average monthly error is $8.7 \%$ while the error relative to the total yearly consumption is only $2.5 \%$. Hence, the estimates agree well with the actual consumption values. The only anomaly appears to be for the month of August where the estimated consumption is much higher than the actual, with the error of $23.6 \%$. This may be due to the assumption in the estimates that in August, the hottest month in Turkey, air conditioning is used 50\% more than the average of the other summer months, which may not have been the case for the particular year when the analysis was carried out. To allow for the spread of behaviours and climates considered in the study, the original assumption on the usage of air conditioning in August was retained.

The same approach was then used to estimate electricity consumption by households in the other cities/regions and these results are shown in Table 9. For brevity, only the total yearly consumption is shown but the values were estimated on an hourly basis for each region, taking into account the respective climates and seasonal requirements. These results are available from the authors on request. 
440

441

442

The estimated electricity generation and supply by the hybrid system, obtained using eqns. (2)-(7), are also shown in Table 9. As can be seen, the system can meet from $12.5 \%$ to $18.4 \%$ of the household's annual electricity needs. Cities in southern regions, such as Aydin, Mersin and Mardin, have both higher electricity generation (due to more abundant solar radiation) and higher annual consumption (due to more excessive use of air conditioners during summer) than the northern cities. The city where the system supplies the highest amount of electricity is Mardin (southeastern Anatolia) and the lowest is Samsun (Black Sea region). The reason for this is that they have the highest and lowest solar irradiation, respectively.

Table 8. Estimated vs actual consumption of household electricity (Istanbul)

\begin{tabular}{lccr}
\hline \multicolumn{1}{c}{ Month } & $\begin{array}{c}\text { Estimated consumption } \\
(\mathbf{k W h})\end{array}$ & $\begin{array}{c}\text { Actual consumption } \\
(\mathbf{k W h})\end{array}$ & \multicolumn{2}{c}{$\begin{array}{c}\text { Relative error } \\
(\boldsymbol{\%})\end{array}$} \\
\hline January & 595.7 & 577.7 & 3.0 \\
February & 526.9 & 536.8 & -1.9 \\
March & 513.4 & 563.8 & -9.8 \\
April & 501.7 & 558.0 & -11.2 \\
May & 404.0 & 442.8 & -9.6 \\
June & 475.6 & 517.6 & -8.8 \\
July & 490.4 & 534.4 & -9.0 \\
August & 858.7 & 655.9 & 23.6 \\
September & 672.9 & 653.3 & 2.9 \\
October & 595.1 & 604.9 & -1.7 \\
November & 772.7 & 682.4 & 11.7 \\
December & 912.3 & 812.2 & 11.0 \\
Total & $\mathbf{7 3 1 9 . 4}$ & $\mathbf{7 1 3 9 . 7}$ & $\mathbf{8 . 7}$ \\
\hline
\end{tabular}

${ }^{\mathrm{a}}$ Average error based on the absolute values of errors for each month. The cumulative error over one year is $2.5 \%$, based on the total estimated and actual yearly consumption.

Table 9. Region-wise annual electricity supply by the solar PV-battery system

\begin{tabular}{lccccc}
\hline City (region) & $\begin{array}{c}\text { Total annual } \\
\text { consumption } \\
\text { (kWh) }\end{array}$ & $\begin{array}{c}\text { Generation } \\
\text { by PV } \\
(\mathbf{k W h})\end{array}$ & $\begin{array}{c}\text { Supply by } \\
\text { battery } \\
(\mathbf{k W h})\end{array}$ & $\begin{array}{c}\text { Supply by } \\
\text { PV+battery } \\
\text { (kWh) }\end{array}$ & $\begin{array}{c}\text { Total share of } \\
\text { PV+battery } \\
(\mathbf{\%})\end{array}$ \\
\hline Istanbul (Marmara) & 7319.4 & 971.6 & 200.4 & 1172.0 & $16.0 \%$ \\
Aydin (Aegean) & $10,486.9$ & 1209.6 & 224.4 & 1434.0 & $13.7 \%$ \\
Kirikkale (Central Anatolia) & 6747.6 & 997.7 & 242.3 & 1240 & $18.4 \%$ \\
Samsun (Black Sea) & 7319.4 & 798.6 & 114.6 & 913.2 & $12.5 \%$ \\
Mersin (Mediterranean) & $10,486.9$ & 1286 & 286.8 & 1572.8 & $15.0 \%$ \\
Mardin (Southeastern Anatolia) & $10,894.9$ & 1367.8 & 262.7 & 1630.5 & $15.0 \%$ \\
Erzurum (Eastern Anatolia) & 6783.6 & 1051.4 & 137.2 & 1188.6 & $17.5 \%$ \\
\hline
\end{tabular}

\subsection{Energy payback}

As indicated in Figure 3, the hybrid system provides between 4.7 and eight times more energy than it consumes over its lifetime. Even in the case of Eastern Anatolia (Erzurum), where solar radiation is not as abundant as in the southern regions, it provides approximately six times more energy than it consumes. Although a financial feasibility analysis was outside the scope of this work, it can be inferred from these results that installing the hybrid systems would be economically viable across the climatic regions of Turkey. 


\subsection{Life cycle environmental impacts}

\subsubsection{Individual installations}

The life cycle environmental impacts of the individual hybrid systems in the seven regions considered are given in Figure 4, also showing the contribution of different life cycle stages. The same pattern can be observed in the figure across the impact categories: the systems installed in the southern regions have the lowest and those in the north the highest impacts, with the difference of around $40 \%$ between the minimum and maximum values. This is due to the significant variation in the energy output between the regions, as shown in Figure 3.

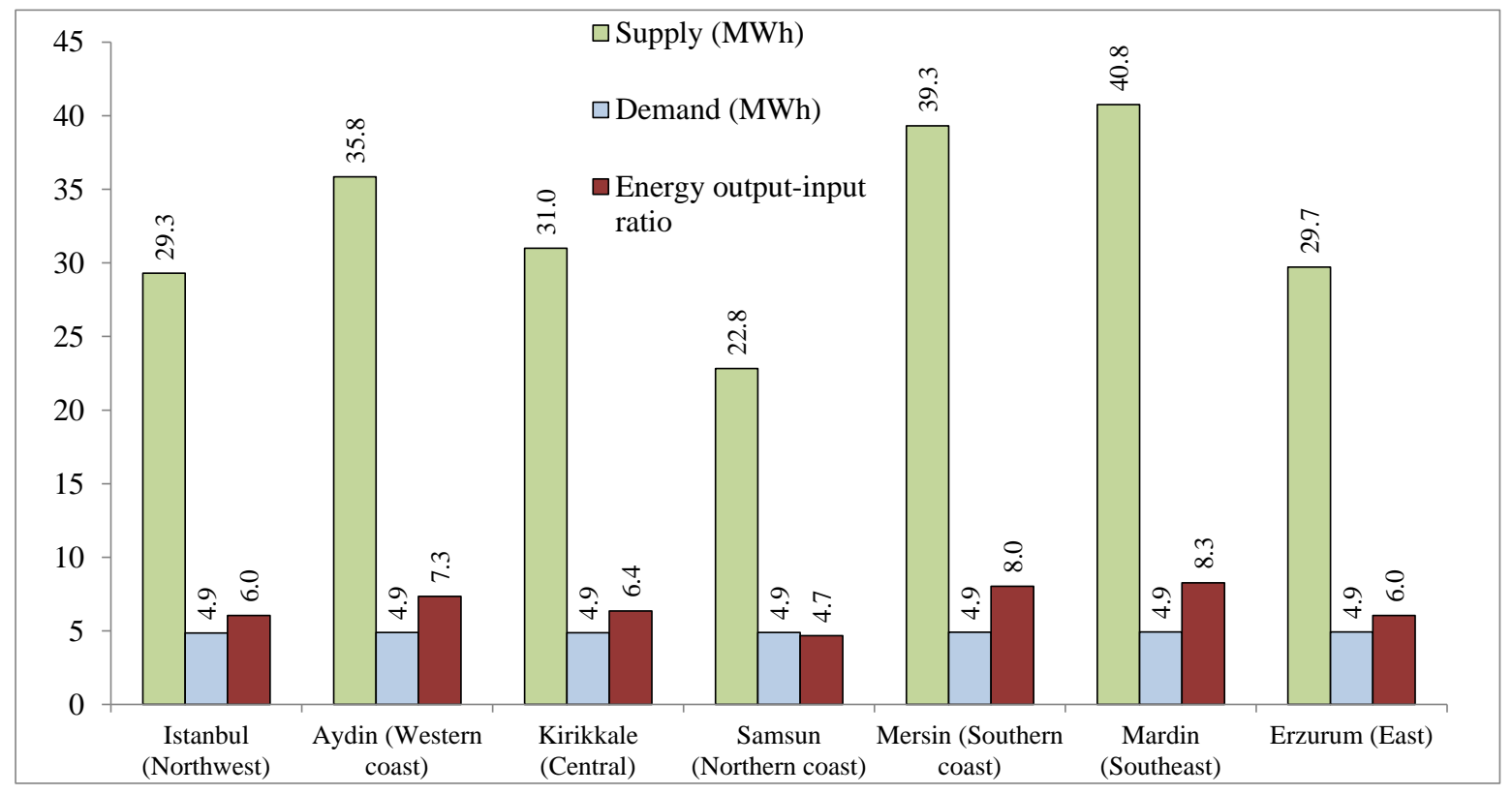

Figure 3. Energy payback for the solar PV-battery system

For most of the impact categories, the main contributor is the manufacture of solar PV panels, causing $75 \%$ of AP, ODP and POCP and $81 \%$ of GWP. The EP is split equally between the PV and the battery. On the other hand, the majority of HTP $(66 \%)$ is due to the battery. For details on the impacts of solar PV and the battery, see Tables S2-S4 and Figure S1 in the SI.

The raw materials and manufacturing of the system components are the main contributors to GWP, $\mathrm{AP}$ and POCP. The remaining three impacts are mainly caused by the raw materials. The contribution of transport and the use stage is insignificant.

The impacts from the raw materials are largely due to the materials used for the PV cell. For GWP, silicon, polyvinyl fluoride film and solar glass account for $45 \%$ of the total impact. A similar trend is found for AP. The raw materials account for more than $80 \%$ of eutrophication, mainly related to aluminium production and silicon purification processes. The main contributors to ozone layer depletion are wafer production used for solar PV and polytetrafluoroethylene used for the battery. Approximately two-thirds of POCP is caused by the raw materials, related to the electricity consumption for silicon production. The contribution of the raw materials is highest for HTP (95\%) and is attributed to the disposal of silicon and wafer waste generated in the manufacturing process. 
In the manufacturing stage, the major contributors are the production of PV cells $(50 \%)$ and the production of the lithium-ion battery $(35 \%)$, followed by the production of the inverter $(15 \%)$.

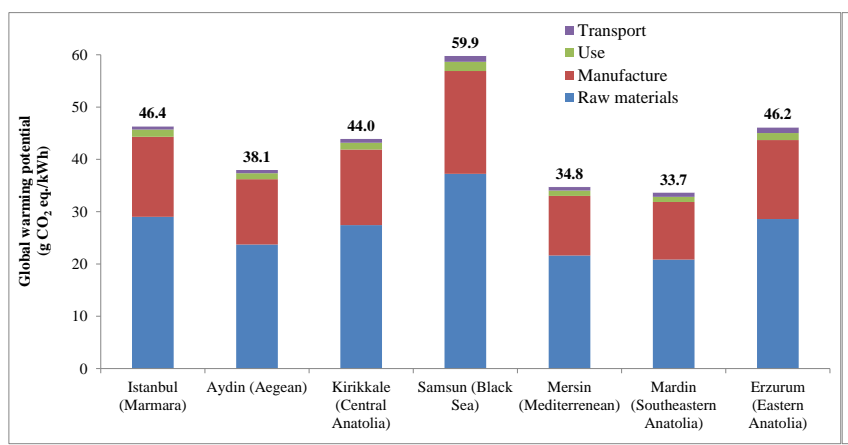

a) Global warming potential

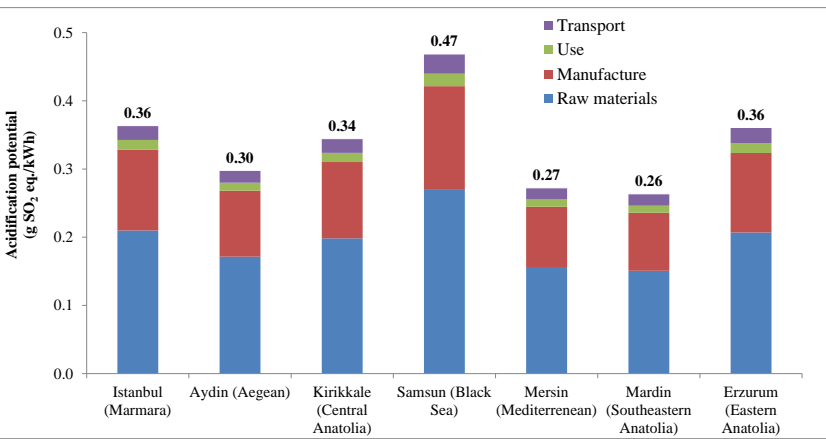

b) Acidification

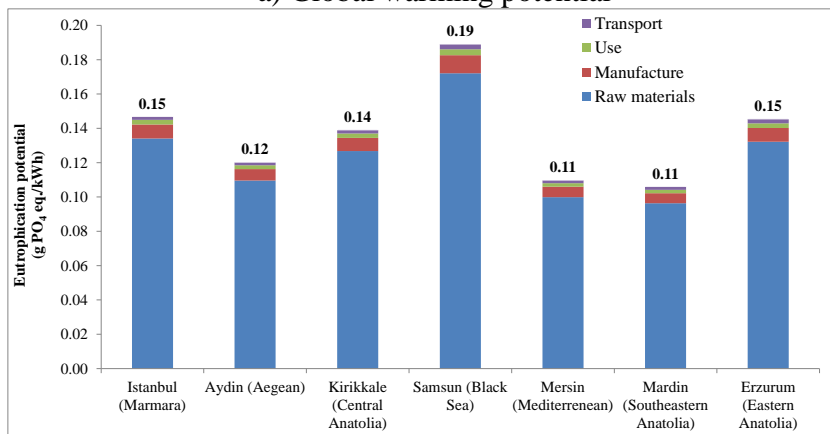

c) Eutrophication

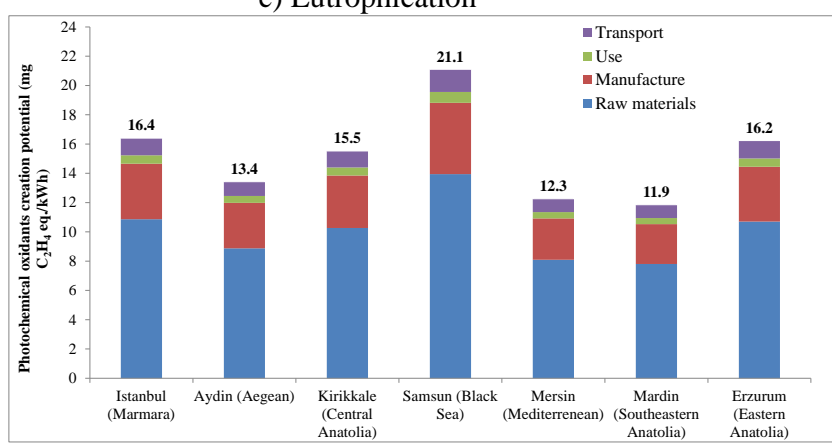

e) Photochemical oxidants

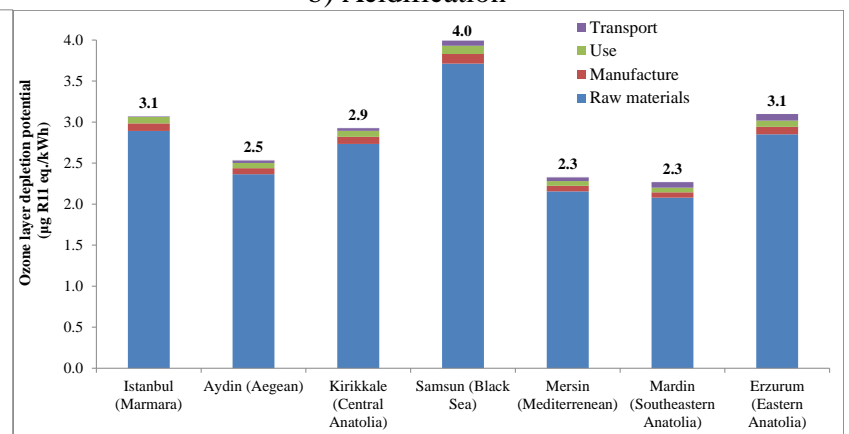

d) Ozone layer depletion

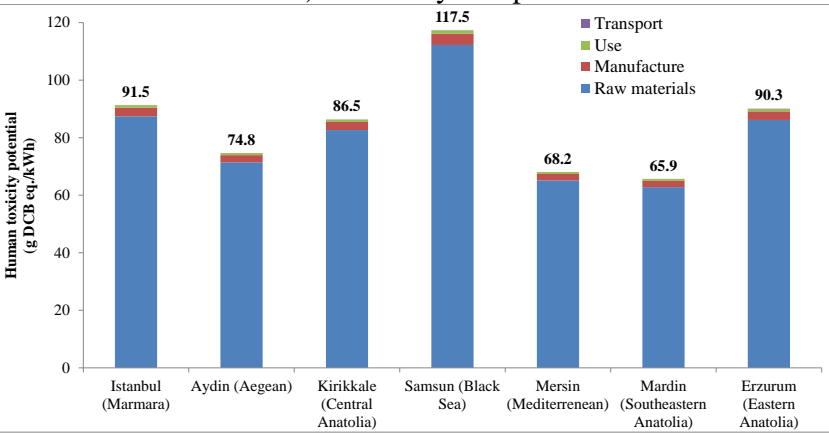

f) Human toxicity

Figure 4. Environmental impacts of the solar PV-battery system for different geographical regions, also showing the contribution of different life cycle stages

(DCB: dicholorobenzene)

493

494

495

496

497

498

499

500 501

\subsubsection{Comparison with grid electricity}

The impacts of the hybrid system averaged across the regions are compared with the environmental impacts of Turkish grid electricity in Figure 5. The hybrid system has 1.6-82.6 times lower impacts, with the former corresponding to eutrophication and the latter to acidification. The high difference in acidification is due to the large share of fossil fuels in the Turkish electricity mix, high sulphur content in domestic coal and a lack of desulphurisation units in power plants. Therefore, deploying the PV-battery system across the country to displace the grid electricity would lead to significant environmental benefits. This is explored further in the next section. 


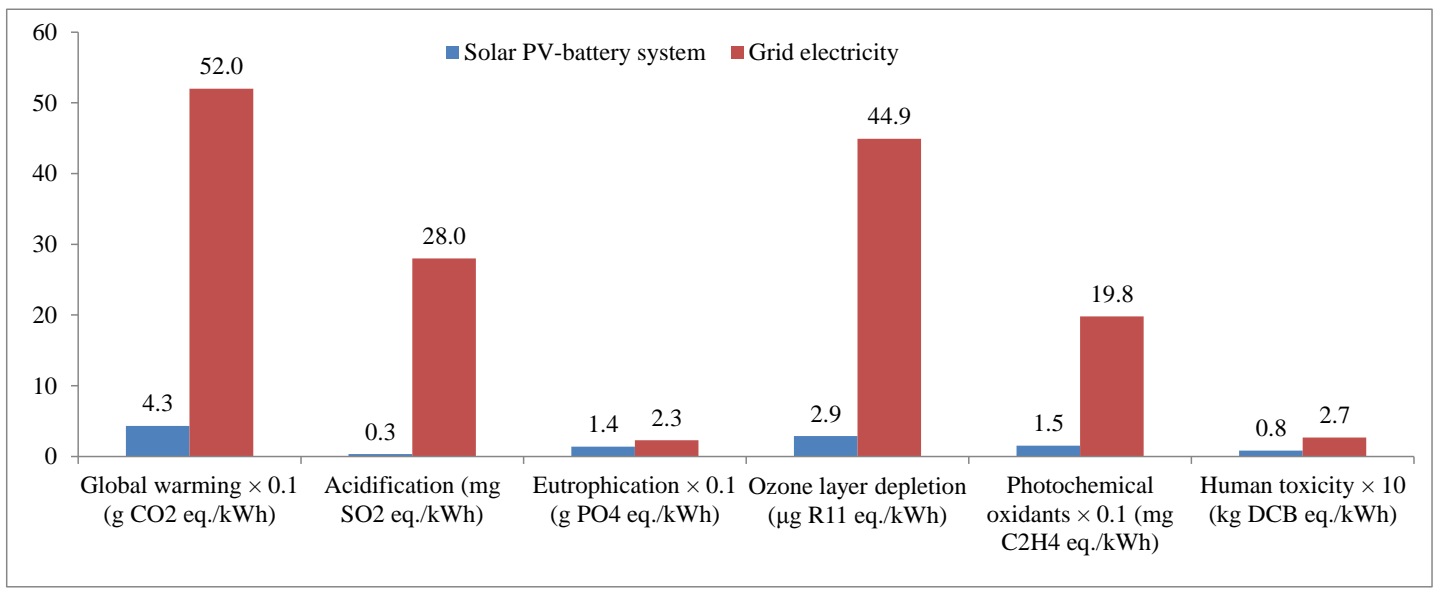

Figure 5. Environmental impacts of electricity supplied by the solar PV-battery system (average across the regions) in comparison with Turkish grid electricity

\subsubsection{Country-wide installations}

507 Based on the values in Table 7 and Table 9, the annual energy supply by the hybrid systems is 508 estimated at $1.073 \mathrm{TWh}$. This is equivalent to $0.4 \%$ of the annual electricity consumption in Turkey of $275 \mathrm{TWh}$ (Enerjiatlasi.com, 2018). The corresponding environmental impacts are shown in Figure 6 in comparison with the impacts of the equivalent amount of grid electricity. As can be seen, significant reductions in the impacts can be achieved, ranging from two to 88 times for eutrophication and the acidification, respectively. The annual reduction in GHG emissions would amount to 558,000 t $\mathrm{CO}_{2}$-eq. Taking into account the total national $\mathrm{GHG}$ emissions of $459.1 \mathrm{Mt}$ $\mathrm{CO}_{2}$-eq. (Turkish Institute of Statistics, 2015), this represents a saving of 0.12\%. Although the GHG savings appear insignificant, the reduction in the other impacts would justify wider deployment of the hybrid systems, together with other benefits, such as lower energy bills for consumers, gains for 518 the national economy due to the reduced costs of imported fuels and improved energy security.

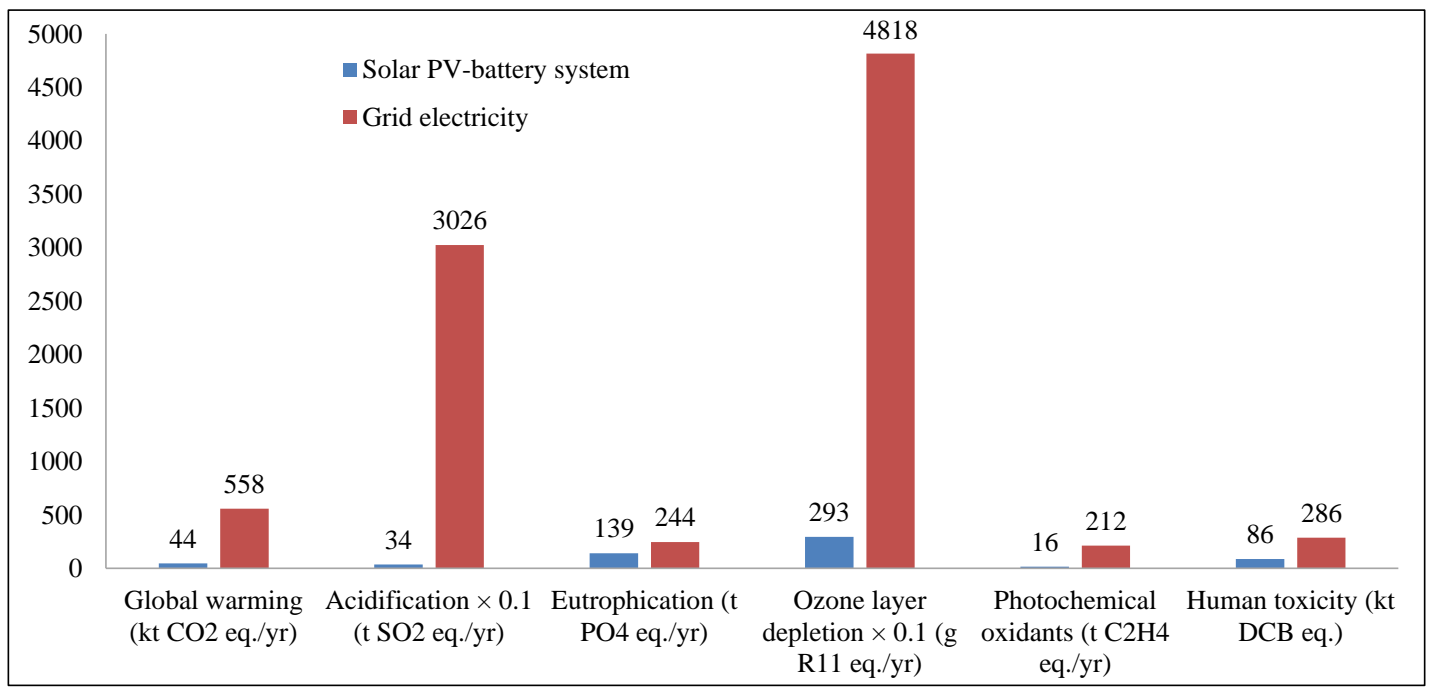

Figure 6. Annual environmental impacts of the hybrid systems at the national level (country average) compared to the grid electricity

(Data for grid electricity sourced from Atilgan and Azapagic (2015). DCB: dichlorobenzene) 


\section{Conclusions}

524 This study presented the life cycle environmental impacts of electricity from a domestic hybrid system integrating solar PV and lithium-ion battery. The impacts were estimated for both individual installations and at the national level, considering seven regions across Turkey and taking into account their insolation levels and other climatic differences. The result show that the system can meet from $12.5 \%$ to $18.4 \%$ of the household's annual electricity needs. On a life cycle basis, it generates 4.7-8 times more energy than it consumes. The main environmental hotspots were found to be the raw materials and the manufacturing of system components, largely related to solar PV, except for human toxicity, which is mainly due to the battery. Among the materials, silicon is the biggest contributor to the impacts, followed by polyvinyl fluoride film and solar glass. In the manufacturing stage, the major contributors are the production of the PV cells, battery and the inverter. The transportation and use stages combined account for less than $10 \%$ across the impact categories.

In comparison with grid electricity, the PV-battery system has significantly lower impacts (1.6-82.6 times). Extrapolating the results to the entire country showed that the annual electricity consumption from the grid can be reduced by $0.4 \%$, saving 558,000 t $\mathrm{CO}_{2}$-eq./yr, or $0.12 \%$ of the national emissions. While this is not significant and will not help Turkey to meet its COP21 targets, the reduction in the other impacts justifies wider deployment of the hybrid systems, together with the financial and energy security benefits for both the country and the consumer.

However, reaching even the conservative uptake levels considered here will be difficult. While the feed-in-tariffs have been effective in stimulating the uptake of solar PV, there are no incentives for consumers to purchase batteries. Perversely, households that have a hybrid system cannot claim the feed-in-tariff for the excess electricity generated as the relevant laws excludes battery storage from the definition of 'renewable energy'. As the results of this work show clearly, integrated PV-battery installations have significant environmental and socio-economic advantages over the grid electricity, thus providing a strong impetus for policy makers to amend legislation and stimulate the uptake of hybrid systems.

\section{References}

Akbari, H. et al., 2018. Efficient energy storage technologies for photovoltaic systems. Solar Energy (article in press).

Altuntop, N. \& Erdemir, D., 2013. Development of the solar energy in Turkey and around the world. Mühendis ve Makina, 54(639), pp. 69-77.

Anon., 2009. Türk Halkı Sitede Oturmak İstemiyor (in Turkish). [Online] Available at: http://www.yapi.com.tr/haberler/turk-halki-sitede-oturmayi-istemiyor 66021.html [Accessed 211 2016].

Atilgan, B. \& Azapagic, A., 2016. Life cycle environmental impacts of electricity from fossil fuels in Turkey. Journal of Cleaner Production, Volume 106, pp. 555-564.

Balcombe, P., Rigby, D. \& Azapagic, A., 2015. Environmental impacts of microgeneration: Integrating solar PV, Stirling engine CHP and battery storage. Applied Energy, Volume 139, pp. 245-259.

Baranes, E., Jacqmin, J. \& Poudou, J., 2017. Non-renewable and intermittent renewable energy sources: Friends and foes?. Energy Policy, Volume 111, pp. 58-67.

Bekkelund, K., 2013. A Comparative Life Cycle Assessment of PV Solar Systems. Trondheim: Norwegian University of Science and Technology.

Belmonte, N. et al., 2016. A comparison of energy storage from renewable sources through batteries and fuel cells: A case study in Turin, Italy. International Journal of Hydrogen Energy , 41(46), pp. 21427-21438. Çakay, R., 2003. Energy of Turkey in 2023. Istanbul: Istanbul Technical University. 
Cheng, M. et al., 2016. Economic and energy consumption analysis of smart building - MEGA house. Building and Environment, Volume 100, pp. 215-226.

Chinese European Energy News, 2017. Power Statistics China 2016. [Online] Available at: http://ceenews.info/en/power-statistics-china-2016-huge-growth-of-renewables-amidstthermal-based-generation/ [Accessed 76 2017].

Corkish, R. \& Prasad, D., 2006. Integrated Solar Photovoltaics for Buildings. Journal of Green Building, 1(2), pp. 63-76.

Deng, Y. et al., 2017. Life cycle assessment of lithium sulfur battery for electric vehicles. Journal of Power Sources, Volume 343, pp. 284-295.

Deng, Y. et al., 2017. Life cycle assessment of high capacity molybdenum disulfide lithium-ion battery for electric vehicles. Energy, Volume 123, pp. 77-88.

Dufo-López, R. et al., 2011. Multi-objective optimization minimizing cost and life cycle emissions of standalone PV-wind-diesel systems with batteries storage. Applied Energy, 88(11), pp. 4033-4041.

Ecoinvent, 2017. Ecoinvent.org. [Online]

Available at: http://www.ecoinvent.org

[Accessed 197 2017].

Enerji Gunlugu, 2014. The 2023 Target for Solar Energy is 5000 MW (in Turkish). [Online] Available at: http://www.enerjigunlugu.net/icerik/10943/gunes-elektriginde-2023-hedefi-5000-mw.html [Accessed 66 2017].

Enerjiatlasi.com, 2018. Annual Electricity Consumption in Turkey. [Online] Available at: http://en.enerjiatlasi.com/electricity-consumption/turkey/ [Accessed 133 2018].

Ferrari, S. \& Beccali, M., 2017. Energy-environmental and cost assessment of a set of strategies for retrofitting a public building toward nearly zero-energy building target. Sustainable Cities and Society, Volume 32, pp. 226-234.

Fraunhofer Institute for Solar Energy Systems, 2016. Photovoltaics Report. [Online] Available at: https://www.ise.fraunhofer.de/de/downloads/pdf-files/aktuelles/photovoltaics-report-inenglischer-sprache.pdf [Accessed 1511 2016].

Fu, H. \& Chen, J., 2017. Formation, features and controlling strategies of severe haze-fog pollutions in China. Science of the Total Environment, Volume 578, pp. 121-138.

Fu, Y., Liu, X. \& Yuan, Z., 2015. Life-cycle assessment of multi-crystalline photovoltaic (PV) systems in China. Journal of Cleaner Production, Volume 86, pp. 180-190.

Gerbinet, S., Belboom, S. \& Leonard, A., 2014. Life cycle analysis (LCA) of solar panels: A review. Renewable Sustainable Energy Reviews, Volume 38, pp. 747-753.

Gong, J., Darling, S. \& You, F., 2015. Perovskite photovoltaics: life-cycle assessment of energy and environmental impacts. Energy and Environmental Science, 8(7), pp. 1953-1968.

Guerin, T., 2017. A case study identifying and mitigating the environmental and community impacts from construction of a utility-scale solar photovoltaic power plant in eastern Australia. Solar Energy, Volume 146, pp. 94-104.

Guinée, J. et al., 2002. Handbook on life cycle assessment. Operational guide to the ISO standards. I: LCA in perspective. IIa: Guide. IIb: Operational annex. III: Scientific background, Dordrecht: Kluwer Academic Publishers.

Hesse, H., Schimpe, M., Kucevic, D. \& Jossen, A., 2017. Lithium-Ion Battery Storage for the Grid-A Review of Stationary Battery Storage System Design Tailored for Applications in Modern Power Grids. Energies, Volume 10, pp. 1-42.

Hou, G. et al., 2016. Life cycle assessment of grid-connected photovoltaic power generation from crystalline silicon solar modules in China. Applied Energy, Volume 164, pp. 882-890. 
IEA, 2016. International Energy Agency World Energy Statistics and Balances. [Online] Available at: www.iea.org/statistics. [Accessed 2912018 ].

International Energy Agency, 2011. Life Cycle Inventories and Life Cycle Assessment of Photovoltaic Systems, New York - USA: s.n.

International Energy Agency, 2013. Oil and Gas Security - Emergency Response of IEA Countries: Turkey. [Online] Available at: https://www.iea.org/publications/freepublications/publication/2013_Turkey_Country_Chapterfinal_with_1 ast page.pdf [Accessed 1810 2016].

International Energy Agency, 2016. Energy Policies of IEA Countries- Turkey: 2016 Review. [Online] Available at: http://www.iea.org/publications/freepublications/publication/EnergyPoliciesofIEACountriesTurkey.pdf [Accessed 1511 2016].

ISO, 2006a. ISO 14040-Environmental Management - Life Cycle Assessment - Principlesand Framework, Geneva: International Standards Organisation.

ISO, 2006b. ISO 14044 - Environmental Management - Life Cycle Assessment - Requirements and Guidelines, Geneva: International Standards Organization.

Johnson, A., Gutierrez, M., Gouzie, D. \& McAliley, L., 2016. State of remediation and metal toxicity in the Tri-State Mining District, USA. Chemosphere, Volume 144, pp. 1132-1141.

Jossen, A., Garche, J. \& Sauer, D., 2004. Operation conditions of batteries in PV applications. Solar Energy, Volume 76, pp. 759-769.

Kabakian, V., McManus, M. \& Harajli, H., 2015. Attributional life cycle assessment of mounted $1.8 \mathrm{kWp}$ monocrystalline photovoltaic system with batteries and comparison with fossil energy production system. Applied Energy, Volume 154, pp. 428-437.

Kaygusuz, K. \& Sar1, A., 2003. Renewable energy potential and utilization in Turkey. Energy Conversion and Management, Volume 44, pp. 459-478.

Lamnatou, C., Baig, H., Chemisana, D. \& Mallick, T., 2015. Life cycle energy analysis and embodied carbon of a linear dielectric-based concentrating photovoltaic appropriate for building-integrated applications. Energy and Buildings, Volume 107, pp. 366-375.

Latunussa, C., Ardente, F., Blengini, G. \& Mancini, L., 2016. Life Cycle Assessment of an innovative recycling process for crystalline silicon photovoltaic panels. Solar Energy Materials \& Solar Cells, Volume 156, pp. 101-111.

Lawrence Berkeley National Laboratory, 2017. Standby Power Summary Table. [Online] Available at: http://standby.lbl.gov/summary-table.html [Accessed 201766 ].

Leonard, M. \& Michaelides, E., 2018. Grid-independent residential buildings with renewable energy sources. Energy, Volume 148, pp. 448-460.

Liang, Y. et al., 2017. Life cycle assessment of lithium-ion batteries for greenhouse gas emissions. Resources, Conservation and Recycling, Volume 117B, pp. 285-293.

Linssen, J., Stenzel, P. \& Fleer, J., 2015. Techno-economic analysis of photovoltaic battery systems and the influence of different consumer load profiles. Applied Energy (in press), Issue http://dx.doi.org/10.1016/j.apenergy.2015.11.088.

Li, T., Roskilly, A. \& Wang, Y., 2016. A Regional Life Cycle Sustainability Assessment Approach and its Application on Solar Photovoltaic. Beijing, The 8th International Conference on Applied Energy.

Li, T., Roskilly, A. \& Wang, Y., 2017. Life cycle sustainability assessment of grid-connected photovoltaic power generation: A case study of Northeast England. Applied Energy (http://dx.doi.org/10.1016/j.apenergy.2017.07.021).

Liu, X., Kent Hoekman, S., Robbins, C. \& Ross, P., 2015. Lifecycle climate impacts and economic performance of commercial-scale solar PV systems: A study of PV systems at Nevada's Desert Research Institute (DRI). Solar Energy, Volume 119, pp. 561-572. 
McManus, M., 2012. Environmental consequences of the use of batteries in low carbon systems: the impact of battery production. Applied Energy, Volume 93, pp. 288-295.

Menoufi, K., Chemisana, D. \& Rosell, J., 2013. Life Cycle Assessment of a Building Integrated Concentrated Photovoltaic scheme. Applied Energy, Volume 111, pp. 505-514.

Murata, 2018. 2.1 kWh Energy Storage Module System. [Online] Available at: https://www.murata.com/products/batteries/ess/ess2 [Accessed 186 2018].

Nian, V., 2016. Impacts of changing design considerations on the life cycle carbon emissions of solar photovoltaic systems. Applied Energy, Volume 183, pp. 1471-1487.

Paraskevas, D., Kellens, K., Dewulf, W. \& Duflou, J., 2015. Environmental modelling of aluminium recycling: a Life Cycle Assessment tool for sustainable metal management. Journal of Cleaner Production, Volume 105, pp. 357-370.

Peters, J. et al., 2017. The environmental impact of Li-Ion batteries and the role of key parameters - A review. Renewable and Sustainable Energy Reviews, Volume 67, pp. 491-506.

Peters, J. \& Weil, M., 2017. Aqueous hybrid ion batteries - An environmentally friendly alternative for stationary energy storage?. Journal of Power Sources, Volume 364, pp. 258-265.

pvwatts.nrel.gov, 2017. [Online] Available at: http://pvwatts.nrel.gov/ [Accessed 205 2017].

Ravikumar, D. et al., 2017. A climate rationale for research and development on photovoltaics manufacture. Applied Energy, Volume 189, pp. 245-256.

Republic of Turkey - Ministry of Energy, 2013. Turkey's Electricity Demand Projection. [Online] Available at: http://www.enerji.gov.tr/File/?path=ROOT\%2F1\%2FDocuments\%2FE\%C4\%B0GM+Ana+Rapor\%2FSG B-T\%C3\%BCrkiye+Elektrik+Enerjisi+Talep+Projeksiyonu.doc [Accessed 291 2018].

Rudolf, V. \& Papastergiou, K., 2013. Financial analysis of utility scale photovoltaic plants with battery energy storage. Energy Policy, Volume 63, pp. 139-146.

Solar Power Europe, 2017. Global market outlook for solar power 2017-2021. [Online] Available at: www.solarpowereurope.org

[Accessed 2912018 ].

Stamford, L. \& Azapagic, A., 2018. Environmental impacts of solar PV: The effects of technological improvements and transfer of manufacture from Europe to China.. Energy Technology, Cilt In press.

Troy, S. et al., 2016. Life Cycle Assessment and resource analysis of all-solid-state batteries. Applied Energy, Volume 169, pp. 757-767.

Turkish Chamber of Electrical \& Electronics Engineers, 2015. Turkish Electricity Statistics (in Turkish). [Online]

Available at: http://www.emo.org.tr/genel/bizden_detay.php?kod=88369\#.WDcM_rLJyM9

[Accessed 2411 2016].

Turkish Institute of Statistics, 2015. Turkish Institute of Statistics, 2015. Greenhouse Gas Emission Inventory of Turkey (in Turkish). [Online]

Available at: http://www.tuik.gov.tr/PreHaberBultenleri.do?id=18744 [Accessed 2011 2016].

Turkish Institute of Statistics, 2016. Population of Turkish cities with respect to year. [Online] Available at: http://www.tuik.gov.tr/PreIstatistikTablo.do?istab id=1590 [Accessed 211 2016].

Turkish Institute of Statistics, 2016. Turkish Population Statistics (in Turkish). [Online] Available at: $\underline{w w w . t u i k . g o v . t r / P r e I s t a t i s t i k T a b l o . d o ? i s t a b \_i d=1591}$ [Accessed 2912018 ].

Turkyilmaz, O., 2015. Ocak 2015 Itibartyla Türkiye'nin Enerji Görünümü Raporu (in Turkish), Istanbul: Union of Chambers of Turkish Engineers and Architects. 
Üçtuğ, F. \& Azapagic, A., 2018. Life cycle environmental impacts of domestic solar water heaters in Turkey: The effect of different climatic regions. Science of The Total Environment, Volume 622-623, pp. 12021216.

Üçtuğ, F. \& Yükseltan, E., 2012. A linear programming approach to household energy conservation: Efficient allocation of budget. Energy and Buildings, Volume 49, pp. 200-208.

UNFCCC, 2017. Republic of Turkey - Nationally Determined Contributions. [Online] Available at:

http://www4.unfccc.int/submissions/INDC/Published\%20Documents/Turkey/1/The_INDC_of_TURKEY -v.15.19.30.pdf

[Accessed 2912018 ].

Unites States Energy Information Administration, 2016. International Energy Outlook 2016, Washington DC: EIA.

Vandepaer, L., Cloutier, J. \& Amor, B., 2017. Environmental impacts of Lithium Metal Polymer and Lithium-ion stationary batteries. Renewable and Sustainable Energy Reviews, Volume 78, pp. 46-60.

Wong, J., Royapoor, M. \& Chan, C., 2016. Review of life cycle analyses and embodied energy requirements of single-crystalline and multi-crystalline silicon photovoltaic systems. Renewable and Sustainable Energy Reviews, Volume 58, pp. 608-618.

www.world-nuclear.org, 2015. The Nuclear Debate. [Online]

Available at: http://www.world-nuclear.org/information-library/current-and-future-generation/the-nucleardebate.aspx

[Accessed 76 2017].

Zackrisson, M. et al., 2016. Life cycle assessment of lithium-air battery cells. Journal of Cleaner Production, Volume 135, pp. 299-311.

Ziyadi, M., Ozer, H., Kang, S. \& Al-Qadi, I., 2018. Vehicle energy consumption and an environmental impact calculation model for the transportation infrastructure systems. Journal of Cleaner Production, Volume 174, pp. 424-436. 


\title{
Environmental impacts of small-scale hybrid energy systems: Coupling solar photovoltaics and lithium-ion batteries
}

\author{
Fehmi Gorkem Üçtuğ and Adisa Azapagic
}

\section{Supplementary information}

\section{S1. Household questionnaire to determine the electricity consumption profile}

1. What time do you get up during weekdays/weekends?

2. What time do you have breakfast during weekdays/weekends?

3. What time do you leave the house during weekdays?

4. What time do you usually come back home from work/school during weekdays?

5. What time do you usually have dinner during weekdays/weekends?

6. What time do you go to sleep on weekdays/weekends?

7. During weekends, what time do you usually have lunch (if eating at home)?

8. Do you get the hot water from an electrical water heater?

9. How often do you use the dishwasher and the washing machine and in which mode (energy-saving, normal, high-temperature, etc.)?

10. On a typical day, how many hours is the television on?

11. How many mobile phones are there in the house and how many times a day is each of them charged?

12. While all the occupants are out of the house, are any electrical appliances (except for the refrigerator) kept running or at standby mode? If yes, specify. If any light bulbs are left on, please indicate which room.

Table S1. An example of the estimated household energy profiles and the usage of the solar PV-battery system ${ }^{\mathrm{a}}$ (Solar PV: $1 \mathrm{kWp}$, lithium-ion battery: $2.1 \mathrm{kWh}$ )

\begin{tabular}{|c|c|c|c|c|c|c|c|c|c|}
\hline Month & Day & Hour & $\begin{array}{c}\text { Total } \\
\text { consumption, } \\
E C_{h}(\mathrm{kWh})\end{array}$ & $\begin{array}{c}\mathrm{PV} \\
\text { generation, } \\
E G_{h}(\mathrm{kWh})\end{array}$ & $\begin{array}{c}\text { Storable } \\
\text { electricity, } \\
E S_{h}(\mathrm{kWh})\end{array}$ & $\begin{array}{c}\text { Imported } \\
\text { electricity } \\
\text { (grid), } \\
E I_{h}(\mathrm{kWh})\end{array}$ & $\begin{array}{c}\text { Net energy } \\
\text { stored by } \\
\text { battery, } \\
E S N_{h}(\mathrm{kWh})\end{array}$ & $\begin{array}{c}\text { Net energy } \\
\text { flow in/from } \\
\text { battery, } \\
E N F_{h}(\mathrm{kWh})\end{array}$ & $\begin{array}{c}\text { Net supply } \\
\text { by battery, } \\
E S U P_{h} \\
(\mathrm{kWh})\end{array}$ \\
\hline \multirow{24}{*}{ Jan } & \multirow{24}{*}{1} & 1 & 0.0925 & 0.000 & 0.000 & 0.0925 & 0.000 & 0.000 & 0.000 \\
\hline & & 2 & 0.0925 & 0.000 & 0.000 & 0.0925 & 0.000 & 0.000 & 0.000 \\
\hline & & 3 & 0.0925 & 0.000 & 0.000 & 0.0925 & 0.000 & 0.000 & 0.000 \\
\hline & & 4 & 0.0925 & 0.000 & 0.000 & 0.0925 & 0.000 & 0.000 & 0.000 \\
\hline & & 5 & 0.0925 & 0.000 & 0.000 & 0.0925 & 0.000 & 0.000 & 0.000 \\
\hline & & 6 & 0.0925 & 0.000 & 0.000 & 0.0925 & 0.000 & 0.000 & 0.000 \\
\hline & & 7 & 0.0925 & 0.000 & 0.000 & 0.0925 & 0.000 & 0.000 & 0.000 \\
\hline & & 8 & 0.1925 & 0.098 & 0.000 & 0.0945 & 0.00033 & 0.000 & 0.000 \\
\hline & & 9 & 0.0925 & 0.332 & 0.2395 & 0.000 & 0.2395 & 0.2395 & 0.000 \\
\hline & & 10 & 0.0925 & 0.529 & 0.4365 & 0.000 & 0.676 & 0.4365 & 0.000 \\
\hline & & 11 & 0.0925 & 0.639 & 0.5465 & 0.000 & 1.2225 & 0.5465 & 0.000 \\
\hline & & 12 & 0.0925 & 0.666 & 0.5735 & 0.000 & 1.796 & 0.5735 & 0.000 \\
\hline & & 13 & 0.0925 & 0.599 & 0.5065 & 0.000 & 2.3025 & 0.5065 & 0.000 \\
\hline & & 14 & 0.0925 & 0.457 & 0.3645 & 0.000 & 2.667 & 0.3645 & 0.000 \\
\hline & & 15 & 0.0925 & 0.288 & 0.1955 & 0.000 & 2.8625 & 0.1955 & 0.000 \\
\hline & & 16 & 0.1125 & 0.102 & 0.000 & 0.0105 & 2.852 & -0.0105 & 0.0105 \\
\hline & & 17 & 0.1125 & 0.002 & 0.000 & 0.1105 & 2.7415 & -0.1105 & 0.1105 \\
\hline & & 18 & 0.1125 & 0.000 & 0.000 & 0.1125 & 2.629 & -0.1125 & 0.1125 \\
\hline & & 19 & 0.150 & 0.000 & 0.000 & 0.150 & 2.479 & -0.150 & 0.150 \\
\hline & & 20 & 2.150 & 0.000 & 0.000 & 2.150 & 0.329 & -2.150 & 2.150 \\
\hline & & 21 & 2.150 & 0.000 & 0.000 & 2.150 & 0.000 & -0.329 & 0.329 \\
\hline & & 22 & 0.250 & 0.000 & 0.000 & 0.250 & 0.000 & 0.000 & 0.000 \\
\hline & & 23 & 0.150 & 0.000 & 0.000 & 0.150 & 0.000 & 0.000 & 0.000 \\
\hline & & 24 & 0.150 & 0.000 & 0.000 & 0.150 & 0.000 & 0.000 & 0.000 \\
\hline
\end{tabular}

${ }^{\mathrm{a}}$ The variables in the table correspond to the variables in eqns. (1)-(7) in the paper. 
Table S2: Environmental impacts of solar PV in different regions in Turkey

\begin{tabular}{|c|c|c|c|c|c|c|c|}
\hline \multirow[b]{2}{*}{ Impact } & \multicolumn{7}{|c|}{ Solar PV (1 kWp - including the inverter) } \\
\hline & $\begin{array}{c}\text { Istanbul } \\
\text { (Marmara) }\end{array}$ & $\begin{array}{c}\text { Aydin } \\
\text { (Aegean) }\end{array}$ & $\begin{array}{l}\text { Kirikkale } \\
\text { (Central } \\
\text { Anatolia) }\end{array}$ & $\begin{array}{l}\text { Samsun } \\
\text { (Black } \\
\text { Sea) }\end{array}$ & $\begin{array}{c}\text { Mersin } \\
\text { (Mediterranean) }\end{array}$ & $\begin{array}{c}\text { Mardin } \\
\text { (Southeastern } \\
\text { Anatolia) }\end{array}$ & $\begin{array}{l}\text { Erzurum } \\
\text { (Eastern } \\
\text { Anatolia) }\end{array}$ \\
\hline Global warming potential ( $\mathrm{g} \mathrm{CO}_{2}$ eq./kWh) & 37.5 & 30.8 & 35.6 & 48.5 & 28.2 & 27.3 & 37.4 \\
\hline Acidification potential ( $\mathrm{g} \mathrm{SO}_{2}$ eq./kWh) & 0.3 & 0.2 & 0.2 & 0.4 & 0.2 & 0.2 & 0.3 \\
\hline Eutrophication potential $\left(\mathrm{g} \mathrm{PO}_{4} \mathrm{eq} . / \mathrm{kWh}\right)$ & 0.1 & 0.1 & 0.1 & 0.1 & 0.1 & 0.1 & 0.1 \\
\hline Ozone layer depletion potential ( $\mu \mathrm{g}$ R11 eq./kWh) & 2.4 & 1.9 & 2.2 & 3.0 & 1.8 & 1.8 & 2.4 \\
\hline Photochemical oxidants creation potential $\left(\mathrm{mg} \mathrm{C}_{2} \mathrm{H}_{4}\right.$ eq./kWh) & 12.3 & 10.0 & 11.6 & 15.8 & 9.2 & 8.9 & 12.1 \\
\hline Human toxicity potential (g DCB ${ }^{\mathrm{a}}$ eq./kWh) & 30.8 & 25.2 & 29.2 & 39.6 & 23.0 & 22.2 & 30.4 \\
\hline
\end{tabular}

Human toxicity potential (g DCB ${ }^{\mathrm{a}}$ eq./kWh)

Table S3: Environmental impacts of Lithium-ion battery in different regions in Turkey

\begin{tabular}{|c|c|c|c|c|c|c|c|}
\hline \multirow[b]{2}{*}{ Impact } & \multicolumn{7}{|c|}{ Lithium ion battery } \\
\hline & $\begin{array}{c}\text { Istanbul } \\
\text { (Marmara) }\end{array}$ & $\begin{array}{c}\text { Aydin } \\
\text { (Aegean) }\end{array}$ & $\begin{array}{l}\text { Kirikkale } \\
\text { (Central } \\
\text { Anatolia) }\end{array}$ & $\begin{array}{c}\text { Samsun } \\
\text { (Black Sea) }\end{array}$ & $\begin{array}{c}\text { Mersin } \\
\text { (Mediterranean) }\end{array}$ & $\begin{array}{c}\text { Mardin } \\
\text { (Southeastern } \\
\text { Anatolia) }\end{array}$ & $\begin{array}{l}\text { Erzurum } \\
\text { (Eastern } \\
\text { Anatolia) }\end{array}$ \\
\hline Global warming potential $\left(\mathrm{g} \mathrm{CO}_{2}\right.$ eq./kWh $)$ & 8.9 & 7.3 & 8.4 & 11.4 & 6.7 & 6.4 & 8.8 \\
\hline Acidification potential ( $\mathrm{g} \mathrm{SO}_{2}$ eq./kWh) & 0.1 & 0.1 & 0.1 & 0.1 & 0.1 & 0.1 & 0.1 \\
\hline Eutrophication potential ( $\mathrm{g} \mathrm{PO}_{4}$ eq./kWh) & 0.1 & 0.1 & 0.1 & 0.1 & 0.1 & 0.1 & 0.1 \\
\hline Ozone layer depletion potential ( $\mu \mathrm{g}$ R11 eq./kWh) & 0.7 & 0.6 & 0.7 & 1.0 & 0.6 & 0.6 & 0.7 \\
\hline Photochemical oxidants creation potential $\left(\mathrm{mg} \mathrm{C}_{2} \mathrm{H}_{4}\right.$ eq. $\left./ \mathrm{kWh}\right)$ & 4.2 & 3.4 & 3.9 & 5.3 & 3.1 & 3.0 & 4.1 \\
\hline Human toxicity potential (g DCB $\left.{ }^{\mathrm{a}} \mathrm{eq} . / \mathrm{kWh}\right)$ & 60.7 & 49.6 & 57.4 & 77.9 & 45.2 & 43.7 & 59.9 \\
\hline
\end{tabular}

an toxicity potential $\left(\mathrm{g} \mathrm{DCB}^{\mathrm{a}} \mathrm{eq} . / \mathrm{kWh}\right)$

${ }^{a}$ DCB: Dichlorobenzene.

Table S4: Total environmental impacts in different regions in Turkey

\begin{tabular}{|c|c|c|c|c|c|c|c|}
\hline \multirow[b]{2}{*}{ Impact } & \multicolumn{7}{|c|}{ Total } \\
\hline & $\begin{array}{c}\text { Istanbul } \\
\text { (Marmara) }\end{array}$ & $\begin{array}{c}\text { Aydin } \\
\text { (Aegean) }\end{array}$ & $\begin{array}{l}\text { Kirikkale } \\
\text { (Central } \\
\text { Anatolia) }\end{array}$ & $\begin{array}{c}\text { Samsun } \\
\text { (Black Sea) }\end{array}$ & $\begin{array}{c}\text { Mersin } \\
\text { (Mediterranean) }\end{array}$ & $\begin{array}{c}\text { Mardin } \\
\text { (Southeastern } \\
\text { Anatolia) }\end{array}$ & $\begin{array}{l}\text { Erzurum } \\
\text { (Eastern } \\
\text { Anatolia) }\end{array}$ \\
\hline Global warming potential ( $\mathrm{g} \mathrm{CO}_{2}$ eq./kWh) & 46.4 & 38.1 & 44.0 & 59.9 & 34.8 & 33.7 & 46.2 \\
\hline Acidification potential ( $\mathrm{g} \mathrm{SO}_{2}$ eq. $\left./ \mathrm{kWh}\right)$ & 0.4 & 0.3 & 0.3 & 0.5 & 0.3 & 0.3 & 0.4 \\
\hline Eutrophication potential $\left(\mathrm{g} \mathrm{PO}_{4}\right.$ eq./kWh) & 0.1 & 0.1 & 0.1 & 0.2 & 0.1 & 0.1 & 0.1 \\
\hline Ozone layer depletion potential ( $\mu \mathrm{g}$ R11 eq./kWh) & 3.1 & 2.5 & 2.9 & 4.0 & 2.3 & 2.3 & 3.1 \\
\hline Photochemical oxidants creation potential $\left(\mathrm{mg} \mathrm{C}_{2} \mathrm{H}_{4}\right.$ eq./kWh) & 16.4 & 13.4 & 15.5 & 21.1 & 12.3 & 11.9 & 16.2 \\
\hline Human toxicity potential (g DCB ${ }^{\mathrm{a}}$ eq./kWh) & 91.5 & 74.8 & 86.5 & 117.5 & 68.2 & 65.9 & 90.3 \\
\hline
\end{tabular}

${ }^{\mathrm{a}}$ DCB: Dichlorobenzene. 

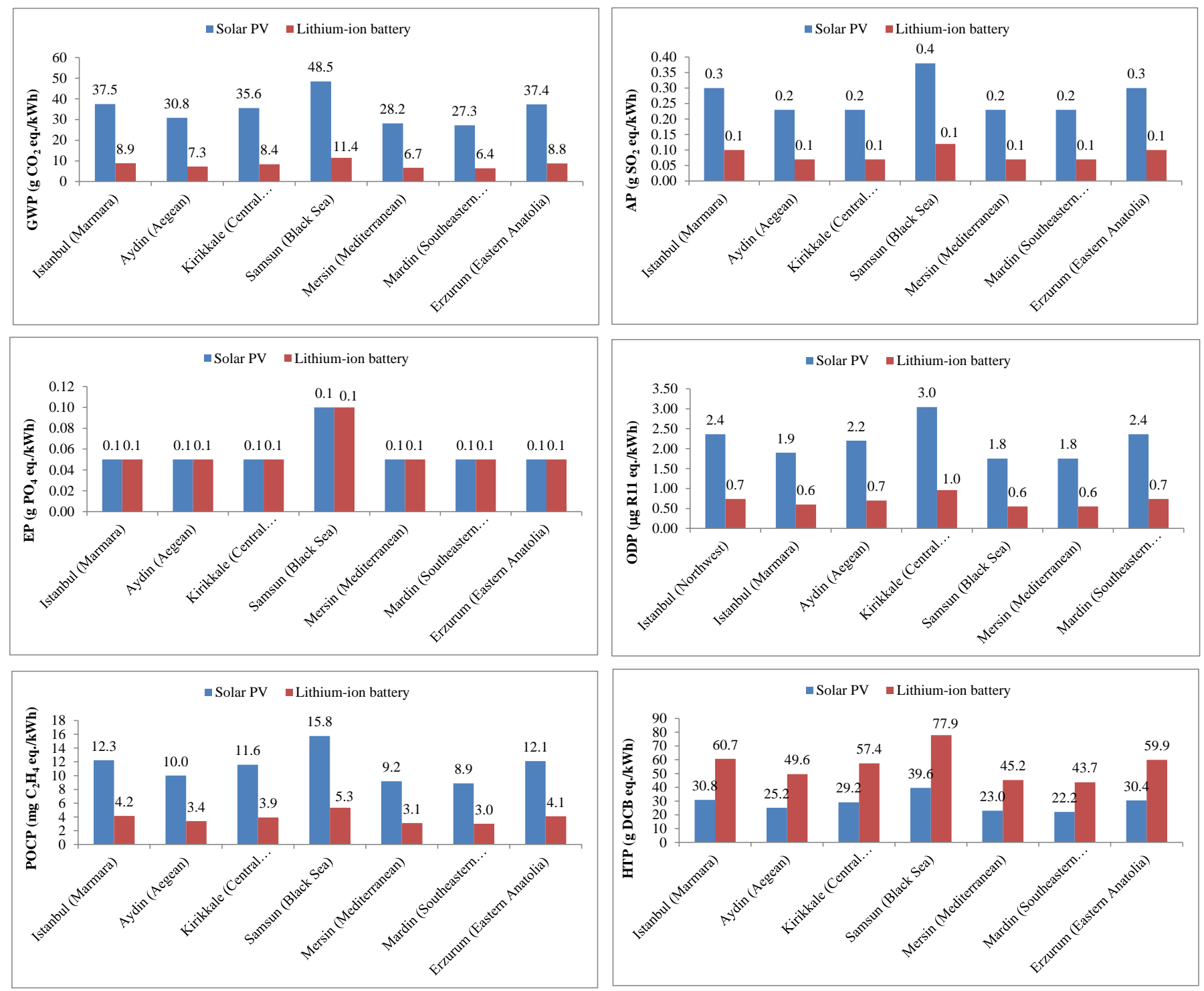

Figure S1: Environmental impacts of solar PV and lithium-ion battery in different regions 